This is a postprint version of the following published document:

Tsipas, S. A., \& Gordo, E. (2016). MolybdenoAluminizing of Powder Metallurgy and Wrought Ti and Ti-6Al-4V alloys by Pack Cementation process. Materials Characterization, [In press], Available online 23 June 2016.

DOI: $10.1016 / \mathrm{j}$ matchar.2016.06.028

(C) Elsevier 2016

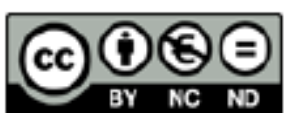

This work is licensed under a Creative Commons Attribution-NonCommercialNoDerivatives 4.0 International License. 


\title{
Molybdeno-Aluminizing of Powder Metallurgy and Wrought Ti and Ti-6Al-4V alloys by Pack Cementation process
}

\author{
Sophia A. Tsipas, ${ }^{*}$ Elena Gordo \\ Department of Materials Science and Engineering, IAAB, Universidad Carlos III de Madrid. Avda. Universidad 30, 28911 Leganés, Spain
}

A B S T R A C T

\begin{abstract}
Wear and high temperature oxidation resistance of some titanium-based alloys needs to be enhanced, and this can be effectively accomplished by surface treatment. Molybdenizing is a surface treatment where molybdenum is introduced into the surface of titanium alloys causing the formation of wear-resistant surface layers containing molybdenum, while aluminizing of titanium-based alloys has been reported to improve their high temperature oxidation properties. Whereas pack cementation and other surface modification methods have been used for molybdenizing or aluminizing of wrought and/or cast pure titanium and titanium alloys, such surface treatments have not been reported on titanium alloys produced by powder metallurgy (PM). Also a critical understanding of the process parameters for simultaneous one step molybdeno-aluminizing of titanium alloys by pack cementation and the predominant mechanism for this process have not been reported. The current research work describes the surface modification of titanium and Ti-6Al-4V prepared by PM by molybdeno-aluminizing and analyzes thermodynamic aspects of the deposition process. Similar coatings are also deposited to wrought Ti-6Al-4V and compared. Characterization of the coatings was carried out using scanning electron microscopy and x-ray diffraction. For both titanium and Ti-6Al-4V, the use of a powder pack containing ammonium chloride as activator leads to the deposition of molybdenum and aluminium into the surface but also introduces nitrogen causing the formation of a thin titanium nitride layer. In addition, various titanium aluminides and mixed titanium aluminium nitrides are formed. The appropriate conditions for molybdeno-aluminizing as well as the phases expected to be formed were successfully determined by thermodynamic equilibrium calculations.
\end{abstract}

Keywords: Ti-6Al-4V, molybdenizing, powder metallurgy, thermodynamic calculations, pack cementation

\section{Introduction}

Titanium alloys are used in the aerospace, automotive, power generation, chemical, marine, biomedical and sports industries, due to their excellent combination of mechanical properties with low density and corrosion resistance. A limitation for the wider use of titanium alloys in engineering applications is their poor wear behavior and resistance to high temperature oxidation. Surface modification seems to be an effective way to improve these properties of titanium alloys.

Molybdenizing or aluminizing are surface treatments in which molybdenum or aluminium, respectively, are deposited into the surface of alloys in order to improve their environmental resistance. Both molybdenum and aluminum are important alloying elements of titanium alloys. With the addition of molybdenum, the mechanical properties, oxidation and corrosion resistance of titanium alloys can be improved [1,2]. Improvements in the corrosion and wear resistance of titanium has been achieved by using single Mo or multi-element Mo, $\mathrm{Y}, \mathrm{Ti}, \mathrm{Ni}$ and $\mathrm{N}$ implantation [3]. The tribological behavior of thermal [4] and plasma sprayed [5], laser cladded [6], and electro-thermal explosion directional sprayed (ETEDS) [7] molybdenum coatings has also been studied. In this last case of ETEDS the coatings exhibited a compact microstructure, high wear resistance and high bonding strength. Double glow plasma surface alloying (DGPA) technique has been applied to prepare Mo and Mo $\mathrm{N}$ modified layers

\footnotetext{
* Corresponding author

Email address: stsipas@ing.uc3m.es (S.A. Tsipas)
}

on titanium alloys, which show high surface hardness and good tribological behavior [8,9]. The molybdenizing layer is composed of a deposited sub-layer of about $12 \mu \mathrm{m}$ thick and a diffusing sub-layer of about $15 \mu \mathrm{m}$ thick [10]. The wear resistance of the molybdenized Ti-6Al-4V was significantly improved due to the much higher surface hardness compared to the substrate, which reaches values of 1171 HV0.1. Evaluation of the tribological behavior of the molybdenized layer at room temperature and at $500^{\circ} \mathrm{C}$ showed a decrease in wear rate of the Ti-6Al-4V alloy after molybdenizing in both cases. A greater reduction of the friction coefficient and wear rate of the molybdenized layer was observed at $500^{\circ} \mathrm{C}$ as a result of the good self-lubricating properties of Mo at higher temperatures compared to room temperatures [11].

Surface modification of Ti-6Al-4V alloy with Mo-N by DGPA method caused the formation of an outmost layer of $\mathrm{Mo}_{2} \mathrm{~N}$ which showed better friction and wear behavior during sliding against corundum balls in Hanks' solution than that of untreated Ti-6Al-4V alloy [12]. Also this type of Mo-N surface modified layer on Ti-6Al-4V alloy by DGPA method had better chemical corrosion performance in boiling $37 \% \mathrm{HCl}$ solution as compared with that of Ti-6Al-4V alloy [13].

An interesting development concerns the burn resistance of Ti-6Al-4V alloy. A binary Ti-Mo burn-resistant surface layer was deposited on Ti-6Al-4V alloy by DGPA. The alloying element concentration in the surface layer reached $59 \%$ and a depth of 100 microns of burn resistant alloy was achieved. A higher ignition temperature was revealed for the Mo alloyed layer compared to the ignition temperature of the unalloyed Ti-6Al-4V alloy [14]. 
Pack cementation is a well-known coating deposition method that allows formation of coatings in materials with different geometries in a low-cost and flexible manner. The coating is created by submerging the substrate in a powder mixture consisting of the metal to be deposited (metal donor), a halide activator and an inert filler. This powder mixture is placed in a sealed or semi-sealed vessel which is heated to the deposition temperature $\left(700-1150^{\circ} \mathrm{C}\right)$ in a protective atmosphere for a specified period of time. When the deposition temperature is reached a reaction-diffusion process occurs that entails the reaction of the metal donor with the halide activator and the generation of halide vapors in-situ. The halide vapors, in turn, react at the substrate surface and decompose into the metallic element which forms the diffusion coating. Coating characteristics are dependent upon the composition of the powder mixture, the substrate, as well as deposition temperature and time. Adjusting and optimizing these factors, tailor-made coating properties can be achieved $\left[\begin{array}{ll}15 & 18,19\end{array}\right]$.

Both pure titanium and titanium-based alloys have been molybdenized or aluminized using this method in order to improve their wear and high temperature oxidation performance. Molybdenizing of titanium and or titanium alloys by pack cementation has been reported $[20,21]$ using a pack cementation process in the temperature range $800-1100^{\circ} \mathrm{C}$. The coating is made up of a deposited layer and a diffusion layer, with phase composition consisting of $\mathrm{Mo} \rightarrow \beta \rightarrow \alpha^{\prime \prime} \rightarrow \alpha^{\prime}$ moving inwards from the surface, corresponding to different molybdenum contents. Gradual decrease of microhardness values from the deposition layer towards the substrate were observed due the different hardness levels of $\beta, \alpha^{\prime \prime}$ and $\alpha^{\prime}$ phases. Microhardness values about four times higher than that of the untreated titanium substrate were achieved for both the deposition and the diffusion layers [22].

Pure Ti, Ti based alloys and Ti intermetallics have been aluminized in order to improve their high temperature oxidation properties using various methods (laser surface alloying [23], magnetron sputtering [24], thermal spray [25]); however, the two most common methods used for Ti aluminizing are pack cementation aluminizing [26 29] and

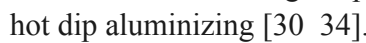

Using the pack cementation method the coating is formed as a result of diffusion of Al contained in the powder pack. Various works [26 28 $]$ concluded that pack aluminizing of Ti-based alloys produces a $\mathrm{TiAl}_{3}$ coating layer. This layer, when exposed to oxidation in air at high temperature forms a continuous $\mathrm{Al}_{2} \mathrm{O}_{3}$ scale on the surface that provides excellent oxidation resistance up to $800^{\circ} \mathrm{C}[26,27]$. The oxide layers acts as a barrier to the diffusion of oxygen into the substrate and is more protective than a mixture of $\mathrm{Al}_{2} \mathrm{O}_{3} / \mathrm{TiO}_{2}$ scale [35]. Pt-modified aluminide coating formed by pack aluminizing shows superior oxidation resistance over plain aluminide coating on titanium IMI-834 alloy in air in the temperature range $650800{ }^{\circ} \mathrm{C}\left[\begin{array}{ll}35 & 38\end{array}\right]$. In a another study the oxidation behavior of aluminide coating on $\mathrm{Ti} 6 \mathrm{Al} 4 \mathrm{~V}$ alloy changed when $\mathrm{Y}_{2} \mathrm{O}_{3}$ was used instead of $\mathrm{Al}_{2} \mathrm{O}_{3}$ as inter filler in the pack, being about 5 times faster in the initial 10h [29]. Furthermore, the addition of a small amount of $\mathrm{Nb}$ or $\mathrm{Cr}$ in the Ti alloy has also been reported to improve the oxidation resistance, by changing the crystal structure of $\mathrm{Al}_{3} \mathrm{Ti}$ from low symmetry DO22 to high symmetry LI2 [39].

The hot-dip aluminizing process consists essentially of immersion of titanium/titanium alloy in a bath of molten aluminum or aluminum alloy bath for a certain time, followed by diffusion annealing $[34,40]$. During the reaction of liquid $\mathrm{Al}$ and solid Ti the only product formed is $\mathrm{TiAl}_{3}$ due to its lower free energy of formation among the Ti-aluminides [40]. $\mathrm{TiAl}_{3}$ obtained by hot-dip aluminizing followed by interdiffusion heat treatment exhibited a lower oxidation rate in comparison with the $\mathrm{Ti} 6 \mathrm{Al} 4 \mathrm{~V}$ alloy at $800^{\circ} \mathrm{C}$ and lower temperatures during cyclic oxidation [41]. The oxidation kinetics followed para- bolic relations at $700^{\circ} \mathrm{C}$ and $800^{\circ} \mathrm{C}$ during the isothermal oxidation [34]. The addition of $\mathrm{Ni}, \mathrm{Si}$, and $\mathrm{Cr}$ in the aluminide bath formed a diffusion barrier and prolonged the lifetime of the protective aluminides [30].

Although multielement diffusion coatings have been reported for other elements/substrate systems, to our knowledge no Mo-Al treatment has been reported on titanium alloys produced by powder metallurgy (PM) methods. In addition, it is unclear how the different powder mixture compositions, temperatures and times of treatment influence the type, nature and quality of the final Mo-Al coatings. Furthermore, the differences in the microstructure and surface porosity characteristics of PM titanium and titanium alloys compared to that of wrought titanium alloys will influence the obtained coating. In this work we present the results of Mo-Al co-deposition treatments on titanium and Ti-6Al-4V alloy produced by powder metallurgy compared to wrought alloy. Thermodynamic analysis using Thermocalc computer software program is used in an effort to better understand the thermodynamics of the deposition process.

\section{Materials and methods}

\subsection{Target materials}

The composition of the substrates was pure titanium and the Ti-6Al-4V alloy (Ti $6 \mathrm{wt} \% \mathrm{Al} \quad 4 \mathrm{wt} \% \mathrm{~V}$ ). Conventional powder metallurgy processing was used for manufacturing of the substrates and details of the process can be found elsewhere [42]. Green compacts with a diameter of $16 \mathrm{~mm}$ and $3 \mathrm{~mm}$ in thickness were obtained in a uniaxial die under a pressure of $600 \mathrm{MPa}$, employing zinc stearate as wall-die lubricant. The substrates were subsequently sintered under high vacuum $\left(10^{-5} \mathrm{mbar}\right)$ at $1200^{\circ} \mathrm{C}$ for 2 hours. In addition, substrates made of wrought laminated titanium alloy with dimensions of about 10x15x1 mm and composition Ti $6 \mathrm{wt} \% \mathrm{Al} \quad 4 \mathrm{wt} \% \mathrm{~V}(\mathrm{Ti}-6 \mathrm{Al}-4 \mathrm{~V})$ and were also used. Prior to the coating experiments, samples were cleaned ultrasonically in alcohol, followed by drying and weighing.

\subsection{Thermodynamic calculations}

Thermodynamic software Thernocalc [43] in combination with SSUB4 Substances database version 4 (Scientific Group Thermodata Europe) was utilized for performing thermodynamic equilibrium studies.

\subsection{Coating procedure}

Preparation of the pack powder mixtures was carried out by weighing and mixing correct amounts of powders of metal donor, inert filler material and halide salts (activators). Homogenization of the powder mixture was performed prior to the treatment by mixing for 1 hour in a Turbula ${ }^{\circledR}$ multidirectional mixer. The activator used was $\mathrm{NH}_{4} \mathrm{Cl}$. The metal donors used were $\mathrm{Mo}$ and $\mathrm{Al}$, and $\mathrm{Al}_{2} \mathrm{O}_{3}$ was used as inert filler. The pack mixture was placed in an alumina crucible and the substrates were inserted in the pack mixture. The crucible was introduced in the interior of a semi-airtight refractory metal container that had a separate gas entry and gas exit orifices as well as a thermocouple for controlling the temperature. The box was placed inside a muffle type furnace. The pack was purged with argon prior to the treatment and subsequently the temperature was increased to $100^{\circ} \mathrm{C}$ and held there for $1 \mathrm{~h}$ to remove moisture. Subsequently, temperature was increased to the final coating temperature of $1000^{\circ} \mathrm{C}$ and was held for $6 \mathrm{~h}$. During all heating steps a heating rate of $10^{\circ}$ 
$\mathrm{C} / \mathrm{min}$ was employed. The argon gas flow was continuous throughout the whole heating cycle and cooling cycle. Cooling to room temperature was performed at its natural rate by turning off power supply. In order to avoid oxidising, oxygen-getters consisting of porous samples of pure titanium were placed in the crucible to react with any oxygen present. Diffusion experiments of Mo onto titanium and Ti-6Al-4V substrate were performed by preparation of acetone-based slurries with Mo powder which were applied onto the substrates. The substrates were subsequently heated with a heating and cooling rate of $10^{\circ} \mathrm{C} / \mathrm{min}$ in a vacuum furnace $\left(10^{-5} \mathrm{bar}\right)$ up to a temperature of $1100^{\circ} \mathrm{C}$ and held for $3 \mathrm{~h}$.

\subsection{Characterisation techniques}

Characterization of the deposited layer was performed by examining the cross-section of coated samples by scanning electron microscopy (SEM, Philips XL 30) coupled with Energy Dispersive x-ray Spectroscopy (EDS). A Cu layer was deposited by electrodeposition to all samples before cutting in order to protect the deposited coatings during metallographic preparation. For microstructural observation of the cross-section samples were prepared by standard metallographic techniques, consisting of grinding with $\mathrm{SiC}$ abrasive paper and polishing with alumina. X-ray diffraction was performed on the surface of coated samples prior to $\mathrm{Cu}$ coating application using a X-ray diffractometer (Philips X'Pert-MPD) with monochromatic $\mathrm{Cu} \mathrm{K}_{\alpha}$ radiation in the $2 \theta$ range from 20 to 80 degrees using goniometer step of $0.005^{\circ}$.

\section{Thermodynamic Calculations}

In order to determine the optimum deposition conditions, it is necessary to understand all the steps involved in the pack cementation process which are as follows. Gaseous reactant species (precursors) are formed by reaction of the activators with the metal donor contained in the powder mixture. Upon reaching the heated sample, the gas precursors are absorbed and react at the surface to deposit a stable solid film of the elemental metal donor. Next, formation of the coating occurs by reaction-diffusion between the metal to be deposited and the substrate. The recombination of the gaseous by-products and their de-absorption into the gas phase also takes place. Diffusion in the gas and/or solid phases rather than the surface reaction is thought to be rate controlling [15,16,19,44 47].

Considering the steps involved the capacity of different metal donors and activators to transfer from the packs and deposit onto the substrates depends mainly on the amount/partial pressures of gas precursors that they generate within the packs at the coating temperature, which, in turn, depends on compositions of powder mixtures.

With the objective to predict the gaseous species generated during the during pack cementation for Mo deposition, thermodynamic calculations were executed considering the effect of the variation of the quantity of activator $\mathrm{NH}_{4} \mathrm{Cl}$. For the calculations pure titanium was taken as the substrate and $40 \mathrm{wt} \%$ Mo as the Mo supplier. Neither the alloying elements of Ti-6Al-4V nor the inert $\mathrm{Al}_{2} \mathrm{O}_{3}$ filler were taken into consideration for the thermodynamic calculation.

Firstly, the gas precursor partial pressure for deposition of Mo was determined in order to determine the approximate amount of activator needed. The predicted equilibrium gas composition for a pack mixture consisting of $40 \mathrm{wt} \% \mathrm{Mo}$ at $1000^{\circ} \mathrm{C}$ as a function of the $\mathrm{NH}_{4} \mathrm{Cl}$ activator at atmospheric pressure is shown in Fig. 1a. Above about $2 \mathrm{wt} \% \mathrm{NH}_{4} \mathrm{Cl}$ the partial pressure of gas species containing Mo increases. The presence of Mo-containing gas species, which is a prerequisite for the deposition of Mo onto the substrate, seems to stabi-
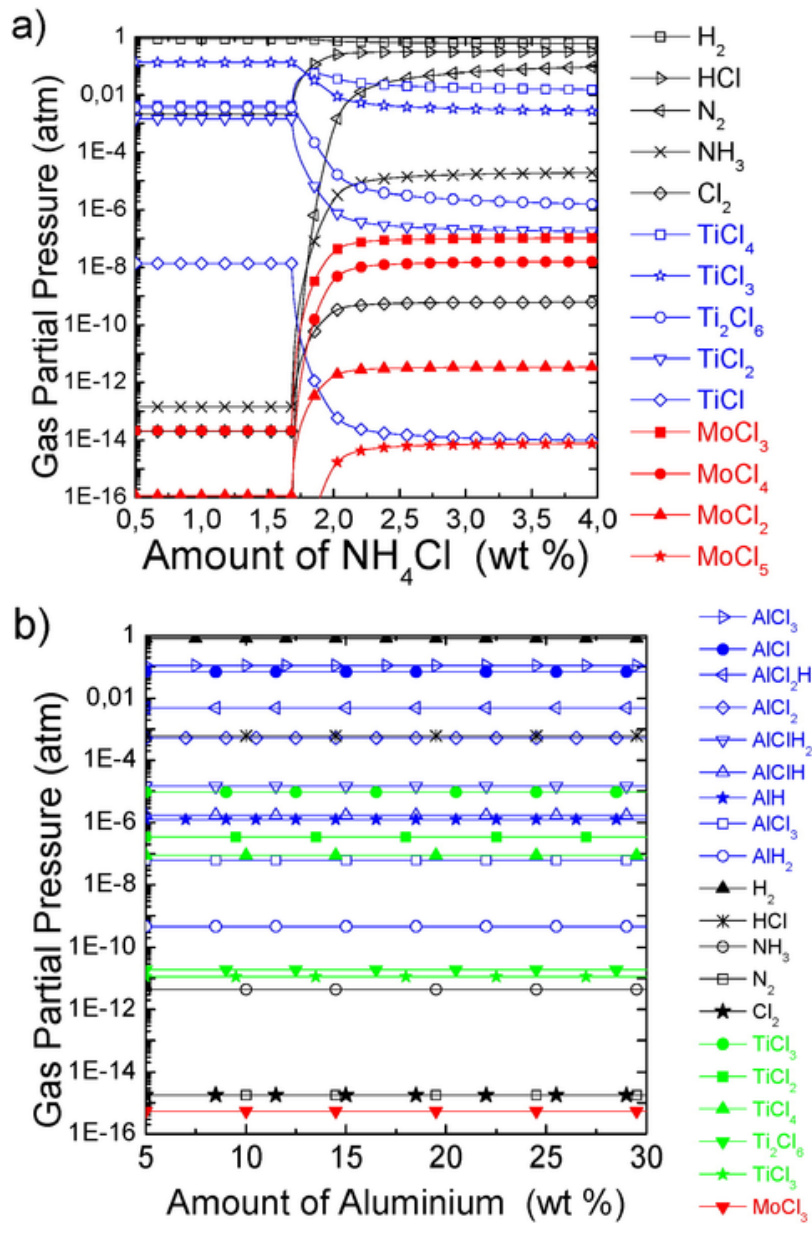

Fig. 1. a) Partial pressure of thermodynamically stable gases with respect to the amount of $\mathrm{NH}_{4} \mathrm{Cl}$ present in a molybdenizing pack that contains $40 \mathrm{wt} \% \mathrm{Mo}$ at $1000^{\circ} \mathrm{C} \mathrm{b}$ ) Gas precursor partial pressure for a pack composition containing $\mathrm{Mo}$ and $\mathrm{Al}$ metal donor and $3 \mathrm{wt} \% \mathrm{NH}_{4} \mathrm{Cl}$ at $1000^{\circ} \mathrm{C}$ as a function of $\mathrm{wt} \%$ of $\mathrm{Al}$ (the total amount of metal donor $\mathrm{Mo}+\mathrm{Al}$ was maintained at $40 \mathrm{wt} \%$ )

lize at around $3 \mathrm{wt} \% \mathrm{NH}_{4} \mathrm{Cl}$. Previous studies have stipulated that Mo deposition in halide-activated pack cementation occurs due to the formation and decomposition of $\mathrm{MoCl}_{3}$ and $\mathrm{MoCl}_{2}$ [21]. However the present thermodynamic calculations confirm the formation of $\mathrm{MoCl}_{4}$ in greater quantities than $\mathrm{MoCl}_{3}$ and in addition the formation of $\mathrm{MoCl}_{5}$. All these chlorides possibly participate in the deposition of Mo onto the substrate. On the other hand, for all amounts of $\mathrm{NH}_{4} \mathrm{Cl}$ a certain amount of Ti-containing gas precursors is also present. Considering that $\mathrm{Ti}$ is a highly active element, this could indicate that the $\mathrm{NH}_{4} \mathrm{Cl}$ partially reacts with the Ti substrate during the deposition process forming volatile species. Previous studies of coatings deposited by pack cementation onto Ti substrates have observed a similar reactivity of the Ti substrate with the pack during the deposition process [16].

Next the partial pressure of gas precursors for a mixture containing $\mathrm{Mo}$ and $\mathrm{Al}$ metal donors plus $3 \mathrm{wt} \% \mathrm{NH}_{4} \mathrm{Cl}$, as a function of aluminium content at $1000^{\circ} \mathrm{C}$ was determined (Fig. 1b). For the calculation the total amount of metal donors $(\mathrm{Mo}+\mathrm{Al})$ was maintained at $40 \mathrm{wt} \%$. The objective was to establish the minimum amount of $\mathrm{Al}$ needed in order to achieve simultaneous co-deposition of Mo and Al. It is widely accepted [46,48 54] that for co-deposition of two elements simultaneously during pack cementation the partial pressure of metal-containing gas precursors of each one of the metals to be de- 
posited has to be similar. Considering the equilibrium partial pressures and the gas species generated it can be observed that even with such a high amount of Mo $(35 \mathrm{wt} \%)$ the dominant gas species contain mainly $\mathrm{Al}$ or $\mathrm{Ti}$, even for as little as $5 \mathrm{wt} \% \mathrm{Al}$. Therefore it appears that the limiting factor would be the generation of Mo-containing gas precursors, whereas $\mathrm{Al}$ deposition would probably be achieved with low amounts of $\mathrm{Al}$ in the pack mixture.

The equilibrium phases that are thermodynamically expected to be formed under the investigated deposition conditions were also by performing thermodynamic calculations (Fig. 2). For this calculation the presence of the titanium substrate was taken into consideration. The alloying elements of Ti-6Al-4V were not considered in the calculation. For Mo deposition it was considered that the quantity of Ti decreases as the quantity of Mo increases, whereas for the co-deposition of Mo-Al it was considered that the amount of Ti increases as the amount of Mo-Al decreases, maintaining the mass ratio of $\mathrm{Mo:Al}$ as 3:1. The phases likely to be formed on a titanium substrate at $1000^{\circ} \mathrm{C}$ using a pack mixture containing $40 \mathrm{wt} \%$ Mo and $3 \mathrm{wt} \% \mathrm{NH}_{4} \mathrm{Cl}$ activator are: TiN and $\beta \mathrm{Ti}$ in addition to Mo whereas when Mo and $\mathrm{Al}$ are co-deposited using a pack mixture with $3 \mathrm{wt} \% \mathrm{NH}_{4} \mathrm{Cl}$ the phases of TiAl and AlN also appear to be stable. Out of the phases that appear to be stable the formation of TiN is of particular interest due to the known wear-resistant properties of this phase.

In summary, from the thermodynamic calculations performed the possible gas species that will favour Mo deposition can be identified
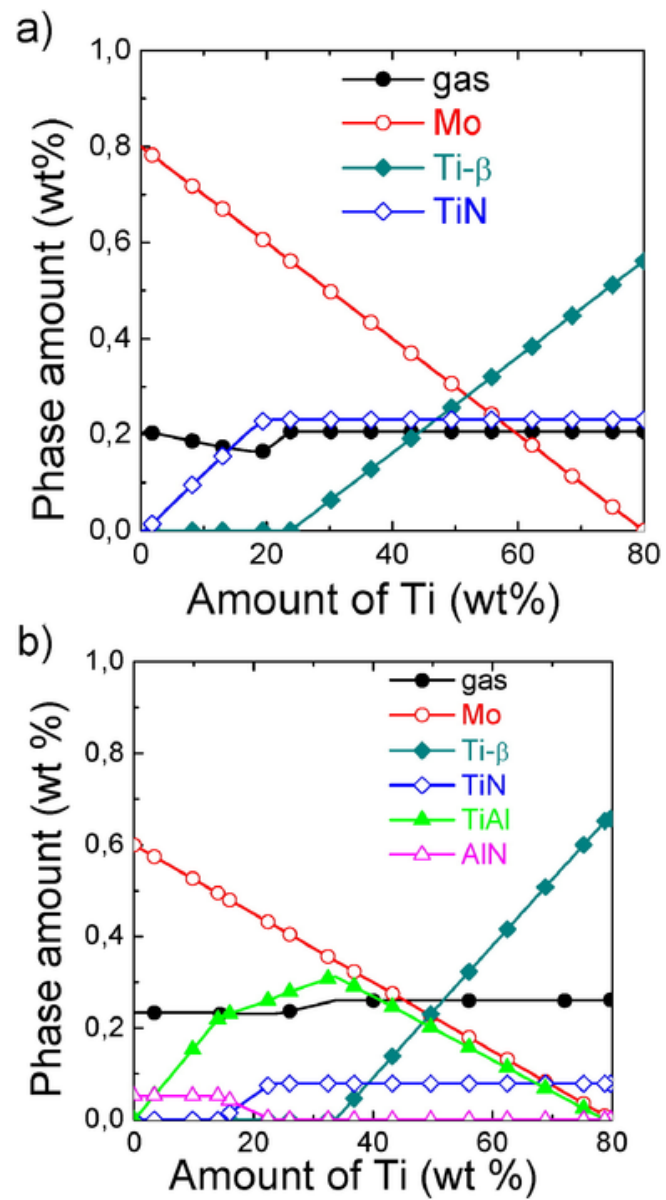

Fig. 2. a)Stable phases at $1000^{\circ} \mathrm{C}$ for a pack containing $3 \mathrm{wt} \% \mathrm{NH}_{4} \mathrm{Cl}$ as a function of amount of Titanium a) for Mo deposition b) for Mo-Al co-deposition (ratio of the amount of Mo:Al as well as the optimum conditions for pack deposition. For a pack mixture at a temperature of $1000^{\circ} \mathrm{C}$, containing $40 \mathrm{wt} \%$ Mo as a metal donor and $3 \mathrm{wt} \%$ of $\mathrm{NH}_{4} \mathrm{Cl}$ as activator successful molybdenizing of titanium would occur. The minimum amount of $\mathrm{Al}$ for co-deposition of $\mathrm{Al}$ and $\mathrm{Mo}$ in a one-step process was estimated to be about $5 \mathrm{wt}$ $\%$ at $1000^{\circ} \mathrm{C}$. The solid phases that are thermodynamically likely to be formed where established: for Mo deposition $\beta \mathrm{Ti}$ and TiN , and for Mo and Al co-deposition $\beta$ Ti, TiN, TiAl and AlN.

\section{Experimental Results and Discussion}

\subsection{Molybenizing of Ti and Ti-6Al-4V}

The cross section and EDS micro analysis of the coatings deposited on PM Ti, PM Ti-6Al-4V and wrought Ti-6Al-4V can be seen in Fig. 3. Several layers can be observed in all cases with similar characteristics in each case. The outermost layer is a protective $\mathrm{Cu}$ layer deposited for protection during metallographic preparation. This is followed by a thin continuous porous layer (layer 1), followed by a bright internal layer (layer 2) and then and third layer with internal porosity (layer 3). The results of EDS microanalysis, which are confirmed by X-ray diffraction (Fig. 4), clearly indicate the existence of a TiN external layer, some micropores (some Mo also was found in this layer) and Mo deposited internally below the TiN layer. A diffusion zone was detected at least up to $25 \mu$ for Ti-6Al-4V substrates and up to about $50 \mu$ for pure titanium substrate and internal pores were observed. The porous layer that separated the diffusion zone from the substrate appears to be more pronounced in wrought Ti-6Al-4V and PM Ti. In addition more pronounced internal porosity is present in pure titanium substrate. X-ray diffraction shown in Fig. 4 confirms the formation of TiN as well as $\alpha+\beta$ titanium in all substrates. In addition peaks corresponding to $\mathrm{Mo}$ and $\mathrm{Al}_{2} \mathrm{O}_{3}$ can be identified, the last one probably as remains of the pack mixture.

For pure titanium $\beta$ transus transformation temperature is around $882^{\circ} \mathrm{C}$, whereas for Ti-6Al-4V is $996^{\circ} \mathrm{C}$. For Ti-6Al-4V produced by powder metallurgy $\beta$ transus the temperature of has been found to be $906^{\circ} \mathrm{C}$, most likely due to the in homogeneity of the starting powder [55]. Therefore, at the deposition temperature the substrate will most likely be in the $\beta$ phase in all cases. The internal porosity and porous layer formed could possibly be due to reaction of the titanium substrate with $\mathrm{NH}_{4} \mathrm{Cl}$ to form titanium chlorides, as predicted by the thermodynamic equilibrium calculations. This could lead to attack of the substrate by the $\mathrm{NH}_{4} \mathrm{Cl}$ and formation of the observed porosity. Similar results have been reported $[16,42]$ and have also been related to the halogen effect. In summary, similar characteristics are observed between Mo deposition in PM Ti-6Al-4V, wrought Ti-6Al-4V and PM Ti. In all cases an internal molybdenum-rich layer is formed as well as $\mathrm{TiN}$, in agreement with thermodynamic calculations. There is an inner porous layer, possibly formed due to the reaction of titanium substrate with the $\mathrm{NH}_{4} \mathrm{Cl}$ activator.

Molybdenizing treatment of $\mathrm{Ti}$ alloys has been carried out using various methods including pack cementation and DGPA technique. When DGPA technique is used, usually a distinct Mo deposited layer is observed, followed by a diffusing layer of similar thickness $[10,11,13,14]$. In the limited number of studies where halide-activated pack cementation is used, the deposition layer contains rests of the pack mixture and undiffused Mo and is followed by a diffusion layer with isolated regions of high Mo content and a phase composition consisting of Mo $\rightarrow \beta \rightarrow \alpha^{\prime \prime} \rightarrow \alpha^{\prime}$ moving inwards from the surface $[21,22]$. Even though similar morphologies are observed as compared to the coatings in this study, the formation of TiN is not re- 
a)

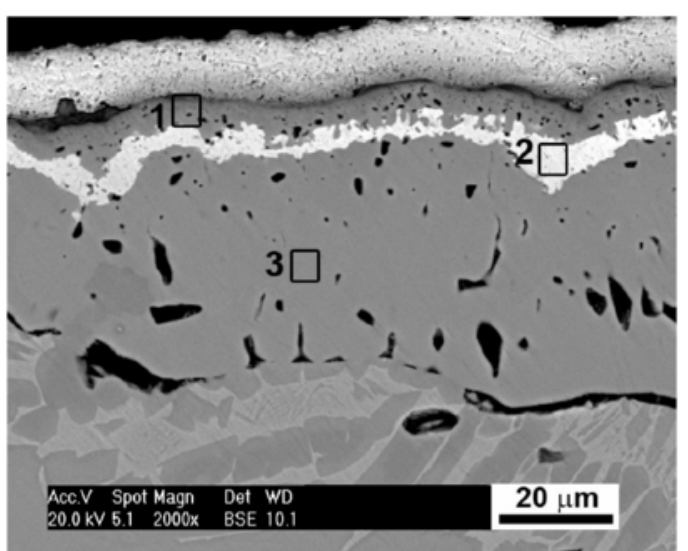

b)

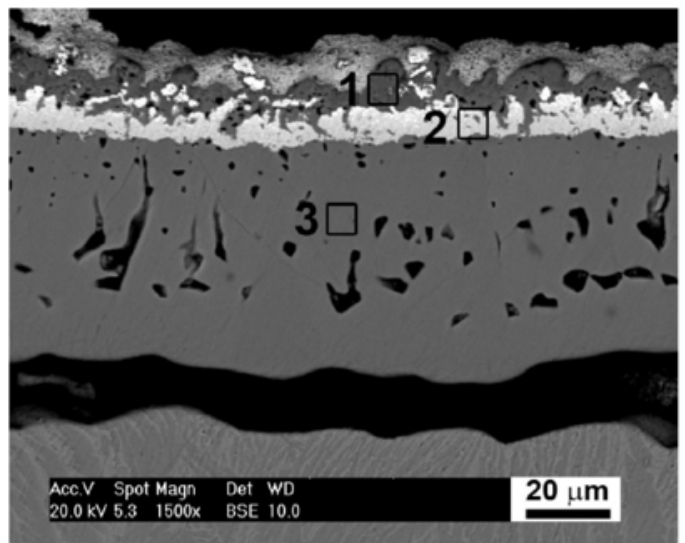

c)

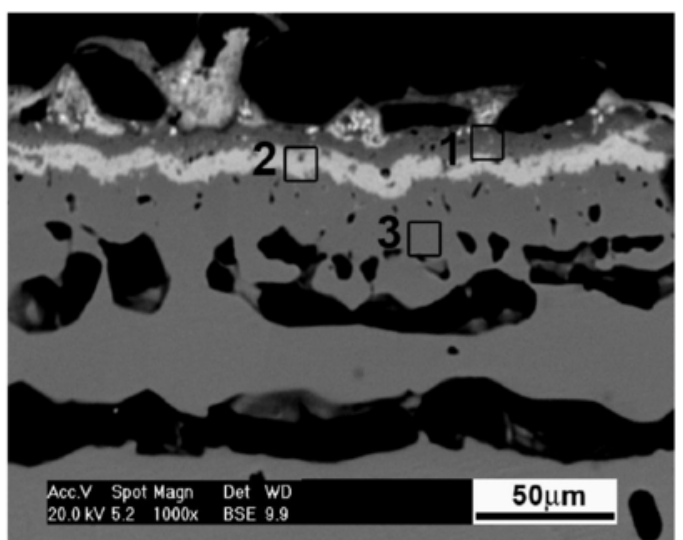

\begin{tabular}{|l|l|l|l|l|}
\hline \multirow{2}{*}{ Layer } & \multicolumn{4}{|l|}{ Atomic \% } \\
\cline { 2 - 5 } & $\mathrm{Ti}$ & $\mathrm{Mo}$ & $\mathrm{N}$ & $\mathrm{Al}$ \\
\hline 1 & 57 & 1 & 41 & 1 \\
\hline 2 & 49 & 9 & 36 & 6 \\
\hline 3 & 59 & 0 & 33 & 8 \\
\hline
\end{tabular}

EDS analysis of Ti-6Al-4V powder metallurgy substrate molybdenized at $1000^{\circ} \mathrm{C}$ for $6 \mathrm{~h}$ in argon atmosphere using a pack with composition of $40 \%$ wt Mo, $3 \%$ wt $\mathrm{NH}_{4} \mathrm{Cl}$

\begin{tabular}{|l|l|l|l|l|}
\hline \multirow{2}{*}{ Layer } & \multicolumn{4}{|l|}{ Atomic \% } \\
\cline { 2 - 5 } & $\mathrm{Ti}$ & $\mathrm{Mo}$ & $\mathrm{N}$ & $\mathrm{Al}$ \\
\hline 1 & 51 & 5 & 44 & 0 \\
\hline 2 & 51 & 29 & 21 & 0 \\
\hline 3 & 70 & 0 & 27 & 3 \\
\hline
\end{tabular}

EDS analysis of Ti-6Al-4V wrought substrate substrate molybdenized at $1000^{\circ} \mathrm{C}$ for $6 \mathrm{~h}$ in argon atmosphere using a pack with composition of $40 \%$ wt Mo, $3 \%$ wt $\mathrm{NH}_{4} \mathrm{Cl}$

\begin{tabular}{|l|l|l|l|}
\hline \multirow{2}{*}{ Layer } & \multicolumn{3}{|c|}{ Atomic \% } \\
\cline { 2 - 4 } & $\mathrm{Ti}$ & $\mathrm{Mo}$ & $\mathrm{N}$ \\
\hline 1 & 66 & 2 & 31 \\
\hline 2 & 73 & 20 & 7 \\
\hline 3 & 80 & 0 & 18 \\
\hline
\end{tabular}

EDS analysis of Titanium powder metallurgy substrate molybdenized at $1000^{\circ} \mathrm{C}$ for $6 \mathrm{~h}$ in argon atmosphere using a pack with composition of $40 \%$ wt Mo, $3 \%$ wt $\mathrm{NH}_{4} \mathrm{Cl}$

Fig. 3. SEM images of cross section (BSE mode) and EDS analysis of deposition layers on substrates molybdenized at $1000^{\circ} \mathrm{C}$ for $6 \mathrm{~h}$ in argon atmosphere using a pack with composition of $40 \%$ wt $\mathrm{Mo}, 3 \% \mathrm{wt} \mathrm{NH}_{4} \mathrm{Cl}$ : a) Ti-6Al-4V powder metallurgy substrate b) Ti-6Al-4V wrought substrate c) Titanium powder metallurgy substrate

ported. This confirms that presence of active $\mathrm{N}$ changes the deposition mechanisms limiting Mo diffusion.

Regarding the possible mechanisms responsible for Mo deposition, Table 1 shows reactions of the Mo-containing gas species with $\mathrm{H}_{2}$, $\mathrm{NH}_{3}$ and $\mathrm{Cl}_{2}$ to form Mo. The gas species considered for the reactions correspond to the species that have been calculated to be thermodynamically stable at the deposition temperature, as shown in Fig. 1. All of the reactions shown in Table 1 have a negative $\Delta G$ at the deposition temperature, which is within the same order of magnitude in all cases (per mole $\mathrm{Mo}_{(\mathrm{s})}$ ). This indicates that they are thermodynamically favorable and spontaneous, and hence likely to lead to Mo de- position. Thermodynamic calculations also showed that Ti-containing gas species are formed at the deposition temperature (Fig. 1). It is believed that these Ti-containing gas species are responsible for the deposition of the TiN layer. The mechanism of deposition will involve the reaction of the Ti-containing gas species to form TiNi. Possible reactions of the Ti-containing gas species with $\mathrm{NH}_{3}, \mathrm{H}_{2}$, and $\mathrm{Cl}_{2}$ to form TiN are shown in Table 2. The reactions shown have negative $\Delta \mathrm{G}$ at the deposition temperature, and therefore are thermodynamically favorable and could be responsible for the formation of the TiN layer observed. 


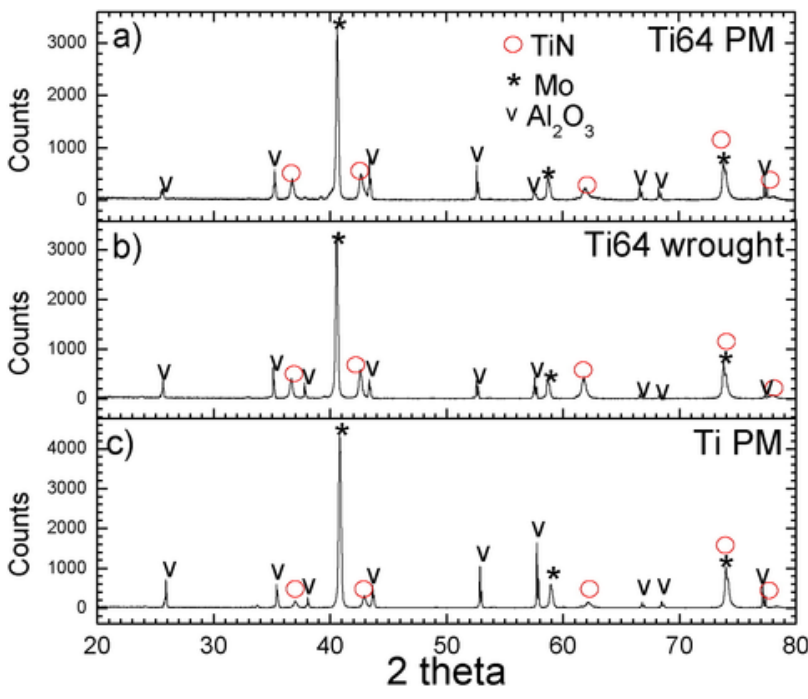

Fig. 4. X-Ray Diffraction diagram of substrates molybdenized at $1000^{\circ} \mathrm{C}$ for $6 \mathrm{~h}$ in argon atmosphere using a pack with composition of $40 \% \mathrm{wt} \mathrm{Mo,} 3 \% \mathrm{wt} \mathrm{NH}_{4} \mathrm{Cl}$ : a) Ti-6Al-4V powder metallurgy substrate b) Ti-6Al-4V wrought substrate c) Titanium powder metallurgy substrate The identification of phases was according to the International Centre for Diffraction Data (ICDD) database: TiN (038-1420), Mo (042-1120), $\mathrm{Al}_{2} \mathrm{O}_{3}$ (042-1468)

To try to understand the formation mechanism of the inner Mo layer and the effect of the activator, Mo was diffused into the surface of both wrought pure titanium and wrought Ti-6Al-4V without the activator. In order to ensure that both substrates were in the $\beta$ phase diffusion was carried out at $1100^{\circ} \mathrm{c}$ for $3 \mathrm{~h}$ in vacuum atmosphere. The cross section of the samples after the diffusion heat treatment is shown in Fig. 5. The outermost layers in both cases correspond to $\mathrm{Cu}$ layer that was applied for protection of the substrate during metallographic preparation. In the case of Ti-6Al-4V a Mo-rich region about $5-10 \mu \mathrm{m}$ in thickness is clearly distinguishable due to its lighter colour in the outermost region of the substrate. This layer is formed by $\alpha+\beta$ colonies of small lamellas. Below this region a homogeneous nearly-equiaxed $\alpha+\beta$ microstructure is observed, which is followed by a more laminar $\alpha+\beta$ microstructure, characteristic of the substrate material. EDS analysis reveals that the Mo is confined mostly to the first $\beta$-rich layer near the outer surface, whereas the next region only experiments a microstructural change consisting on the formation of a $\alpha+\beta$ equiaxed region. In the pure Ti wrought substrate, it appears that Mo diffusion has occurred to about 50-55 $\mu \mathrm{m}$ forming a region of laminar $\alpha+\beta$ microstructure. The different Mo diffusion mechanism is due to the composition of the substrate and their characteristics like thermal conductivity and diffusivity, as well as $\beta$-transus temperature. Considering that thermal conductivity of Ti-6Al-4V alloy $(6.6-6.8 \mathrm{~W} / \mathrm{mK})$ is about three times lower than that of pure $\mathrm{Ti}(17-22 \mathrm{~W} / \mathrm{mK})$ [56], and $\beta$-transus temperature is higher for Ti-6Al-4V alloy, it is possible that different heating and cooling rates and therefore phase transformations are experienced during the experiment for the alloy than the pure Ti substrate.

The presence of $\mathrm{Al}$ and $\mathrm{V}$ alloying elements has modified the diffusion mechanism of Mo into titanium. Vanadium, like molybdenum, is a beta stabilizer alloying element in titanium. The equivalent amount of molybdenum, $\mathrm{Mo}_{\mathrm{eq}}(\mathrm{wt} \%)$ which was calculated using the Molchanova equation[56] considering both the Mo and $\mathrm{V}$ present in the substrate (Fig. 5a) shows that, overall, a higher amount of beta stabilizer elements exists in the Ti-6Al-4V, as compared to pure $\mathrm{Ti}$, as expected.

As a consequence, the outer regions of the Ti-6Al-4V will most likely behave like beta or beta-metastable titanium alloys, whereas in pure titanium the entire diffusion layer will remain in the compositional range of $\alpha+\beta$ titanium alloys. In addition, it is worth noting that in both cases the Mo-rich layer appears at the outer surface and no internal porosity is detected, which confirms that the TiN layer, the inner Mo-rich layer and the porous layer are formed due to the presence of the $\mathrm{NH}_{4} \mathrm{Cl}$ activator.

\subsection{Molybdenizing-Aluminizing of powder metallurgy Ti-6Al-4V}

Mo-Al co-deposition was carried out on PM Ti-6Al-4V substrates using different amounts of $\mathrm{Al}$ and Mo metal donor in the pack composition (Fig. 6). Fig. 6a shows the cross section of the coating deposited using a pack composition containing $35 \mathrm{wt} \% \mathrm{Mo}, 5 \mathrm{wt} \% \mathrm{Al}$ and 3 wt $\% \mathrm{NH}_{4} \mathrm{Cl}$ at $1000^{\circ} \mathrm{C}$ for $6 \mathrm{~h}$. It can be observed that below the $\mathrm{Cu}$ protective layer the diffusion region has a thickness of approximately $30-40 \mu \mathrm{m}$. The outermost layer of the coating (layer 1) is a thin homogeneous layer of about $1-2 \mu \mathrm{m}$, that corresponds to TiN as confirmed by both EDS and x-ray diffraction (Fig. 7a). Layer 2 in Fig. 6a corresponds to an internal Mo-rich region that contains some porosity. It appears that both during Mo deposition as the co-deposition of Mo-Al the Mo layer is present internally when $\mathrm{NH}_{4} \mathrm{Cl}$ is present. This could have interesting implications in the properties, both for wear resistance and for oxidation resistance where it could act as diffusion barrier for $\mathrm{Al}$ outward diffusion. Moving towards the substrate, decreasing amount of aluminium can be detected, corresponding to the different Ti-Al intermetallics. X-ray diffraction shown in

Table 1

Reactions of main Mo-containing gas precursors with $\mathrm{H}_{2(g)}, \mathrm{NH}_{3(\mathrm{~g})}$ and $\mathrm{Cl}_{2(\mathrm{~g})}$ to form $\mathrm{Mo}_{(\mathrm{s})}$

\begin{tabular}{|c|c|c|c|c|c|}
\hline No & Reaction & $\begin{array}{l}\Delta \mathrm{H}^{\circ}\left(1000^{\circ} \mathrm{C}\right) \\
\mathrm{kJ}\end{array}$ & $\begin{array}{l}\Delta \mathrm{S}^{\circ}\left(1000^{\circ} \mathrm{C}\right) \\
\mathrm{J} / \mathrm{K}\end{array}$ & $\begin{array}{l}\Delta \mathrm{Cp}^{\circ}\left(1000^{\circ} \mathrm{C}\right) \\
\mathrm{J} / \mathrm{K}\end{array}$ & $\underset{\mathrm{kJ}}{\Delta \mathrm{G}^{\circ}\left(1000^{\circ} \mathrm{C}\right)}$ \\
\hline 1 & $\mathrm{MoCl}_{3(\mathrm{~g})}+3 / 2 \mathrm{H}_{2(\mathrm{~g})} ? \mathrm{Mo}_{(\mathrm{s})}+3 \mathrm{HCl}_{(\mathrm{g})}$ & $-935123 \times 10^{4}$ & 36882 & -049356 & $-140463 \times 10^{5}$ \\
\hline 2 & $\mathrm{MoCl}_{4(\mathrm{~g})}+2 \mathrm{H}_{2(\mathrm{~g})} ? \mathrm{Mo}_{(\mathrm{s})}+4 \mathrm{HCl}_{(\mathrm{g})}$ & $951929 \times 10^{2}$ & 119072 & $-7,60755$ & $-150627 \times 10^{5}$ \\
\hline 3 & $\mathrm{MoCl}_{2(\mathrm{~g})}+\mathrm{H}_{2(\mathrm{~g})} ? \mathrm{Mo}_{(\mathrm{s})}+2 \mathrm{HCl}_{(\mathrm{g})}$ & $-296961 \times 10^{5}$ & -293705 & 274023 & $-259572 \times 10^{5}$ \\
\hline 4 & $\mathrm{MoCl}_{5(\mathrm{~g})}+5 / 2 \mathrm{H}_{2(\mathrm{~g})} ? \mathrm{Mo}_{(\mathrm{s})}+5 \mathrm{H}_{2(\mathrm{~g})}$ & $-366772 \times 10^{6}$ & 202689 & -150903 & $-294701 \times 10^{5}$ \\
\hline 5 & $\mathrm{MoCl}_{3(\mathrm{~g})}+\mathrm{NH}_{3(\mathrm{~g})} ? \mathrm{Mo}_{(\mathrm{s})}+1 / 2 \mathrm{~N}_{2(\mathrm{~g})}+3 \mathrm{HCl}_{(\mathrm{g})}$ & $-374539 \times 10^{4}$ & 154630 & 124027 & $-234298 \times 10^{5}$ \\
\hline 6 & $3 \mathrm{MoCl}_{4(\mathrm{~g})}+4 \mathrm{NH}_{3(\mathrm{~g})} ? 3 \mathrm{Mo}_{(\mathrm{s})}+2 \mathrm{~N}_{2(\mathrm{~g})}+12 \mathrm{HCl}_{(\mathrm{g})}$ & $227089 \times 10^{5}$ & 828209 & -158873 & $-827220 \times 10^{5}$ \\
\hline 7 & $3 \mathrm{MoCl}_{2(\mathrm{~g})}+2 \mathrm{NH}_{3(\mathrm{~g})} ? 3 \mathrm{Mo}_{(\mathrm{s})}+\mathrm{N}_{2(\mathrm{~g})}+6 \mathrm{HCl}_{(\mathrm{g})}$ & $-778765 \times 10^{5}$ & 147385 & 116884 & $-966386 \times 10^{5}$ \\
\hline 8 & $\mathrm{MoCl}_{2(\mathrm{~g})}+\mathrm{NH}_{3(\mathrm{~g})} ? 3 \mathrm{Mo}_{(\mathrm{s})}+1 / 2 \mathrm{~N}_{2(\mathrm{~g})}+3 / 2 \mathrm{H}_{(\mathrm{g})}+\mathrm{Cl}_{2(\mathrm{~g})}$ & $-511972 \times 10^{4}$ & 763941 & 733206 & $-148447 \times 10^{5}$ \\
\hline 9 & $3 \mathrm{MoCl}_{5(\mathrm{~g})}+5 \mathrm{NH}_{3(\mathrm{~g})} ? 3 \mathrm{Mo}_{(\mathrm{s})}+5 / 2 \mathrm{~N}_{2(\mathrm{~g})}+15 \mathrm{HCl}_{(\mathrm{g})}$ & $170260 \times 10^{5}$ & 119681 & -366018 & $-135328 \times 10^{5}$ \\
\hline 10 & $\mathrm{MoCl}_{3(\mathrm{~g})}+\mathrm{Cl}_{2(\mathrm{~g})}+5 / 2 \mathrm{H}_{2(\mathrm{~g})} ? \mathrm{Mo}_{(\mathrm{s})}+5 \mathrm{HCl}_{(\mathrm{g})}$ & $-283217 \times 10^{5}$ & 488655 & -335155 & $-345423 \times 10^{5}$ \\
\hline 11 & $\mathrm{MoCl}_{4(\mathrm{~g})}+\mathrm{Cl}_{2(\mathrm{~g})}+3 \mathrm{H}_{2(\mathrm{~g})} ? \mathrm{Mo}_{(\mathrm{s})}+6 \mathrm{HCl}_{(\mathrm{g})}$ & $-188753 \times 10^{5}$ & 131056 & -104655 & $-355587 \times 10^{5}$ \\
\hline 12 & $\mathrm{MoCl}_{3(\mathrm{~g})}+\mathrm{Cl}_{2(\mathrm{~g})}+2 \mathrm{H}_{2(\mathrm{~g})} ? \mathrm{Mo}_{(\mathrm{s})}+4 \mathrm{HCl}_{(\mathrm{g})}$ & $-486666 \times 10^{5}$ & -173871 & -011776 & $-464532 \times 10^{5}$ \\
\hline 13 & $\mathrm{MoCl}_{3(\mathrm{~g})}+\mathrm{Cl}_{2(\mathrm{~g})}+7 / 2 \mathrm{H}_{2(\mathrm{~g})} ? \mathrm{Mo}_{(\mathrm{s})}+7 \mathrm{HCl}_{(\mathrm{g})}$ & $-226382 \times 10^{5}$ & 214673 & -179483 & $-499661 \times 10^{5}$ \\
\hline
\end{tabular}


Table 2

Reactions of main Ti-containing gas precursors with $\mathrm{NH}_{3(g)}, \mathrm{H}_{2(g)}$, and $\mathrm{Cl}_{2(\mathrm{~g})}$ to form $\operatorname{TiN}_{(s)}$

\begin{tabular}{|c|c|c|c|c|c|}
\hline No & Reaction & $\begin{array}{l}\Delta \mathrm{H}^{\circ}\left(1000^{\circ} \mathrm{C}\right) \\
\mathrm{kJ}\end{array}$ & $\begin{array}{l}\Delta \mathrm{S}^{\circ}\left(1000^{\circ} \mathrm{C}\right) \\
\mathrm{J} / \mathrm{K}\end{array}$ & $\begin{array}{l}\Delta \mathrm{Cp}^{\circ}\left(1000^{\circ} \mathrm{C}\right) \\
\mathrm{J} / \mathrm{K}\end{array}$ & $\underset{\mathrm{kJ}}{\Delta \mathrm{G}^{\circ}\left(1000^{\circ} \mathrm{C}\right)}$ \\
\hline 1 & $\begin{array}{l}\mathrm{TiCl}_{2(\mathrm{~g})}+ \\
\mathrm{NH}_{3(\mathrm{~g})} ? \\
\mathrm{TiN}_{(\mathrm{s})}+3 / \\
2 \mathrm{H}_{(\mathrm{g})}+\mathrm{Cl}_{2(\mathrm{~g})}\end{array}$ & $-548941 \times 10^{4}$ & -663983 & 855697 & $\begin{array}{l}-464416 \times \\
10^{4}\end{array}$ \\
\hline 2 & $\begin{array}{l}\mathrm{TiCl}_{(\mathrm{g})}+ \\
\mathrm{NH}_{3(\mathrm{~g})} ? \\
\mathrm{TiN}_{(\mathrm{s})}+3 / \\
2 \mathrm{H}_{(\mathrm{g})}+1 / 2 \\
\mathrm{Cl}_{2(\mathrm{~g})}\end{array}$ & $-419651 \times 10^{5}$ & -659305 & 139413 & $\begin{array}{l}-335722 \times \\
10^{5}\end{array}$ \\
\hline 3 & $\begin{array}{l}\mathrm{TiCl}_{3(\mathrm{~g})}+ \\
\mathrm{NH}_{3(\mathrm{~g})}{ }^{+} \\
\mathrm{TiN}_{(\mathrm{s})}+ \\
3 \mathrm{HCl}_{(\mathrm{g})}\end{array}$ & $-418913 \times 10^{4}$ & 765765 & 412750 & $\begin{array}{l}-139373 \times \\
10^{5}\end{array}$ \\
\hline 4 & $\begin{array}{l}\mathrm{TiCl}_{2(\mathrm{~g})}+ \\
\mathrm{NH}_{3(\mathrm{~g})} ? \\
\mathrm{TiN}_{(\mathrm{s})}+ \\
2 \mathrm{HCl}_{(\mathrm{g})}+1 / 2 \\
\mathrm{H}_{2(\mathrm{~g})}\end{array}$ & $-244599 \times 10^{5}$ & 534362 & 569898 & $\begin{array}{l}-251402 \times \\
10^{5}\end{array}$ \\
\hline 5 & $\begin{array}{c}\mathrm{TiCl}_{(\mathrm{g})}+ \\
\mathrm{NH}_{3(\mathrm{~g})} ? \\
\mathrm{TiN}_{(\mathrm{s})}+ \\
\mathrm{HCl}_{(\mathrm{g})}+ \\
\mathrm{H}_{2(\mathrm{~g})}\end{array}$ & $-514504 \times 10^{5}$ & -599388 & 125123 & $\begin{array}{l}-438202 \times \\
10^{5}\end{array}$ \\
\hline 6 & $\begin{array}{l}\mathrm{Ti}_{2} \mathrm{Cl}_{6(\mathrm{~g})}+ \\
2 \mathrm{NH}_{3(\mathrm{~g})} ? \\
2 \mathrm{TiN}_{(\mathrm{s})}+ \\
6 \mathrm{HCl}_{(\mathrm{g})}\end{array}$ & $114496 \times 10^{5}$ & 321711 & 663004 & $\begin{array}{l}-295043 \times \\
10^{5}\end{array}$ \\
\hline 7 & $\begin{array}{l}\mathrm{TiCl}_{4(\mathrm{~g})}+ \\
\mathrm{NH}_{3(\mathrm{~g})} ? \\
\mathrm{TiN}_{(\mathrm{s})}+ \\
3 \mathrm{HCl}_{(\mathrm{g})}+1 / 2 \\
\mathrm{Cl}_{2(\mathrm{~g})}\end{array}$ & $199538 \times 10^{5}$ & 163741 & 305369 & $\begin{array}{l}-890442 \times \\
10^{5}\end{array}$ \\
\hline 8 & $\begin{array}{l}\mathrm{TiCl}_{4(\mathrm{~g})}+ \\
\mathrm{NH}_{3(\mathrm{~g})}+1 / 2 \\
\mathrm{H}_{2(\mathrm{~g})} ? \mathrm{TiN}_{(\mathrm{s})} \\
+4 \mathrm{HCl}_{(\mathrm{g})}\end{array}$ & $104685 \times 10^{5}$ & 169733 & 162469 & $\begin{array}{l}-111384 \times \\
10^{5}\end{array}$ \\
\hline 9 & $\begin{array}{l}\mathrm{TiCl}_{4(\mathrm{~g})}+ \\
\mathrm{NH}_{3(\mathrm{~g})}+1 / 2 \\
\mathrm{Cl}_{2(\mathrm{~g})} ? \mathrm{TiN}_{(\mathrm{s}} \\
+3 \mathrm{HCl}_{(\mathrm{g})}\end{array}$ & $-339452 \times 10^{5}$ & 113354 & 426998 & $\begin{array}{l}-353882 \times \\
10^{5}\end{array}$ \\
\hline 10 & $\begin{array}{l}\mathrm{TiCl}_{4(\mathrm{~g})}+ \\
\mathrm{NH}_{3(\mathrm{~g})}+ \\
\mathrm{Cl}_{2(\mathrm{~g})} ? \mathrm{TiN}_{(\mathrm{s}} \\
+\mathrm{HCl}_{(\mathrm{g})}\end{array}$ & $-704209 \times 10^{5}$ & -479553 & 965434 & $\begin{array}{l}-643162 \times \\
10^{5}\end{array}$ \\
\hline
\end{tabular}

Fig. 7a indicates, in addition to TiN, the presence of TiAl and of $\mathrm{Ti}_{2} \mathrm{AlN}$. $\mathrm{Ti}_{2} \mathrm{AlN}$ compound belongs to the $\mathrm{M}_{\mathrm{n}+1} \mathrm{AX}$ phase (where $\mathrm{n}$ is 1,2 or $3, \mathrm{M}$ is an early transition metal, $\mathrm{A}$ is an A-group element, and $\mathrm{X}$ is either $\mathrm{C}$ or $\mathrm{N}$ ). This nitride displays a unique combination of properties, including low density, high elastic modulus, easy machinability, and excellent thermal shock resistance and damage tolerance [57]. Czyrska-Filemonowicz et al. [58] demonstrated that $\mathrm{Ti}_{2} \mathrm{AlN}$ formed on titanium alloy substrates during glow discharge treatment, and that its presence improved biocompatibility, hardness and wear resistance. Hence, the presence of this compound in the present coating could also contribute to improvement of temperature and wear resistance.

The formation of TiN and TiAl during Mo-Al co-deposition was accurately predicted by the thermodynamic calculations. The presence of $\mathrm{Ti}_{2} \mathrm{AlN}$, which was not predicted from the thermodynamic calculations, confirms the importance of the increased reactivity of
Nitrogen with the Ti substrate, which has been previously observed and reported in other thermochemical treatments on Ti alloys [16]. Different mechanisms can be proposed to explain its formation, the most predominant being incorporation of $\mathrm{N}$ into the Ti-Al intermetalllic compounds formed as a result of aluminizing.

For a pack composition of $30 \mathrm{wt} \% \mathrm{Mo}, 10 \mathrm{wt} \% \mathrm{Al}$ and $3 \mathrm{wt} \%$ $\mathrm{NH}_{4} \mathrm{Cl}$ (Fig. 6b) they outer TiN layer was not detected by EDS, however, TiN was clearly identified by XRD as the main phase present (Fig. 7b) and therefore is most probably present in the outermost layer. This layer is followed by Al-rich layers which, according to X-ray diffraction and EDS, correspond to TiAl and $\mathrm{Ti}_{2} \mathrm{AlN}$. An inner-Mo-rich layer is present, which is discontinuous, due to the presence of less amount of Mo in the pack composition. In addition X-ray reveals the formation of AlN, which is not present in the coating deposited using a pack composition containing a lower amount of Al (Fig. 7a). The presence of AIN is in agreement with the thermodynamic calculations that predict its formation for higher $\mathrm{Al}$ percentages.

\subsection{Molybdenizing-Aluminizing of wrought Ti- $6 \mathrm{Al}-4 \mathrm{~V}$}

Fig. 8 shows the cross section of wrought Ti-6Al-4V substrates after Mo-Al co-deposition with pack compositions of $35 \% \mathrm{wt} \mathrm{Mo,} 5 \mathrm{wt} \%$ $\mathrm{Al}, 3 \% \mathrm{wt} \mathrm{NH}_{4} \mathrm{Cl}$ (Fig. 8a) and 30\%wt Mo, $10 \mathrm{wt} \% \mathrm{Al}, 3 \% \mathrm{wt} \mathrm{NH}_{4} \mathrm{Cl}$ ((Fig. 8b), respectively. Similar characteristics can be observed in both coatings. There is a thin TiN outer layer, followed by an Al-rich region that also contains $\mathrm{N}$ and then an inner Mo-rich layer. Decreasing amount of $\mathrm{Al}$ and also $\mathrm{N}$ can be found moving inwards towards the substrate. EDS analysis and X-ray diffraction (Fig. 9) confirm the presence of TiN as well as mixed Ti-Al nitrides such as $\mathrm{Ti}_{2} \mathrm{AlN}$ and $\mathrm{Ti}_{3} \mathrm{AlN}$. In addition $\mathrm{Ti}_{3} \mathrm{Al}$ appears to be present. The presence of $\mathrm{TiAl}$, which was detected for PM Ti-6Al-4V substrates, is not observed. So, it appears that wrought Ti-6Al-4V favours the formation of Ti-Al mixed nitrides, over the formation of TiAl phase.

In order to understand the influence of the substrate on the phases formed during the pack cementation process, the substrates were examined. Fig. 10 shows the microstructure of the two substrates. The microstructure of the powder metallurgy substrate is much coarser than the microstructure of the wrought substrate and in addition porosity is present in the powder metallurgy substrate. Therefore it appears that grain size and porosity have an effect on the phases that are most likely to be formed.

\subsection{Molybdenizing-Aluminizing of powder metallurgy Ti}

The cross-sections of the powder metallurgy pure titanium substrates after Mo-Al co-deposition are shown in Fig. 11. In these samples the Mo-rich inner layer observed in all the previous cases is not visible in the cross-section and Mo diffusion was not detected by EDS analysis. The cross section shows decreasing amount of Al moving from the outer surface towards the substrate as well as the presence of $\mathrm{N}$. The presence of titanium aluminides (TiAl, $\left.\mathrm{Ti}_{3} \mathrm{Al}\right)$, mixed Ti$\mathrm{Al}$ nitride $\left(\mathrm{Ti}_{2} \mathrm{AlN}\right)$ and a small amount of TiN is confirmed by X-ray diffraction (see Fig. 12). No Mo diffusion is observed for pure titanium during Mo-Al co-deposition by pack cementation, as opposed to both PM and wrought Ti-6Al-4V substrates. It appears that the presence of $\mathrm{Al}$ and $\mathrm{V}$ alloying elements in the substrate favours Mo deposition during pack cementation. Thermodynamic calculations and experimental studies give evidence indicating that it is easy to deposit Al onto titanium substrates, whereas simultaneous diffusion of Mo is more difficult to achieve. (See Fig. 12.) 
a)

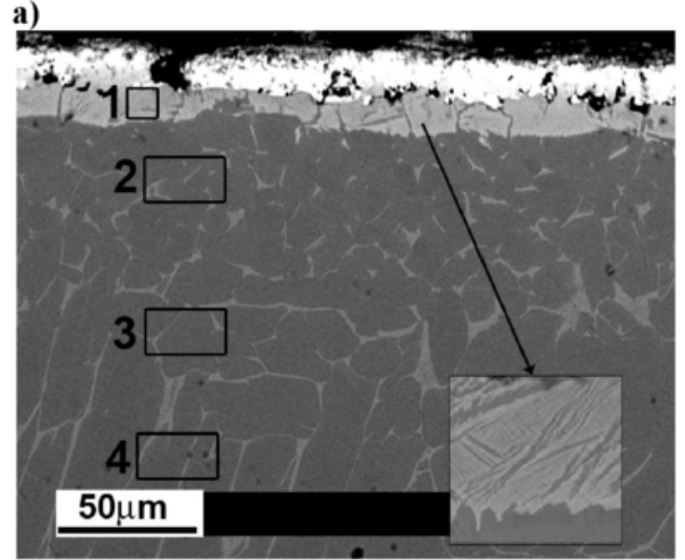

\begin{tabular}{|l|l|l|l|l|c|}
\hline \multirow{2}{*}{ Layer } & \multicolumn{4}{|c|}{ Atomic \% } & \multirow{2}{*}{$\begin{array}{c}\text { Mo } \\
\text { ny }\end{array}$} \\
\cline { 2 - 5 } & $\mathrm{Ti}$ & $\mathrm{Mo}$ & $\mathrm{Al}$ & $\mathrm{V}$ & $($ wt \%) \\
\hline 1 & 85.5 & 3.5 & 7.5 & 3.5 & 9.4 \\
\hline 2 & 86.4 & 0.5 & 11 & 2.1 & 2.5 \\
\hline 3 & 85.1 & 0.1 & 11.8 & 3 & 2.6 \\
\hline 4 & 85 & 0 & 11.4 & 3.6 & 3 \\
\hline
\end{tabular}

EDS analysis of wrought Ti-6Al-4V substrate with Mo surface diffusion at $1100^{\circ} \mathrm{C}$ for $3 \mathrm{~h}$ in vacuum without activator. $\mathrm{Mo}_{\mathrm{eq}}(\mathrm{wt} \%)=[\mathrm{Mo}]+$ $0.67[\mathrm{~V}]+0.2[\mathrm{Ta}]+0.28[\mathrm{Nb}]+0.4[\mathrm{~W}]+1.25[\mathrm{Cr}]+$ $1.25[\mathrm{Ni}]+1.7[\mathrm{Mn}]+1.7[\mathrm{Co}]+2.5[\mathrm{Fe}]$

b)

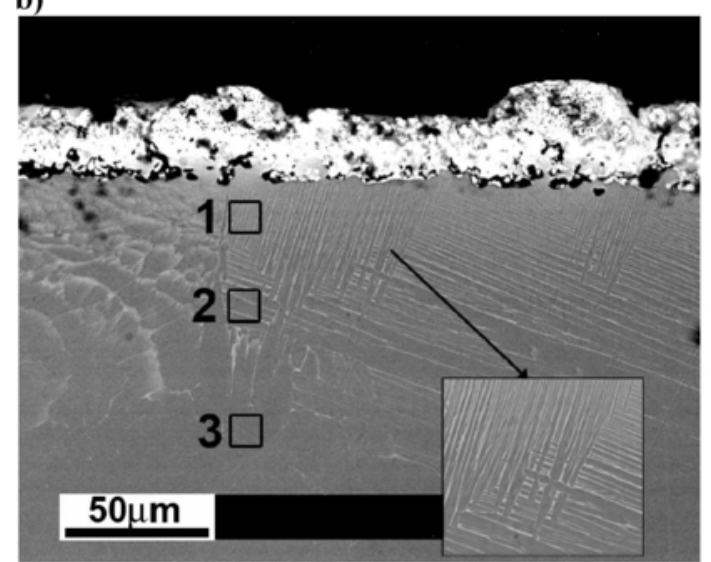

\begin{tabular}{|l|l|l|c|}
\hline \multirow{2}{*}{ Layer } & \multicolumn{2}{|l|}{ Atomic \% } & Weight \% \\
\cline { 2 - 4 } & $\mathrm{Ti}$ & Mo & Mo \\
\hline 1 & 96 & 4.1 & 7.9 \\
\hline 2 & 99 & 0.9 & 1.8 \\
\hline 3 & 100 & 0 & 0 \\
\hline
\end{tabular}

EDS analysis of wrought Ti substrate with Mo surface diffusion at $1100^{\circ} \mathrm{C}$ for $3 \mathrm{~h}$ in vacuum without activator

Fig. 5. SEM images of cross section (BSE mode) of wrought substrates with Mo surface diffusion at $1100^{\circ} \mathrm{C}$ for 3 hours in vacuum without activator a) Ti-6Al-4V b) Ti

\section{Conclusions}

Successful molybdenizing and molybdenizing aluminizing of wrought and powder metallurgy Ti-6Al-4V substrates was achieved in a one-step process, using pack cementation with $\mathrm{NH}_{4} \mathrm{Cl}$ as activator. Thermodynamic calculations were used in order to define the optimum deposition conditions and predict the phases that were likely to form. Molybdenizing in a powder mixture containing $3 \mathrm{wt} \% \mathrm{NH}_{4} \mathrm{Cl}$ activator at $1000^{\circ} \mathrm{C}$ leads to the formation of a uniform thin external TiN and in the interior a Mo diffused layer on both Ti and Ti-6Al-4V powder metallurgy and wrought Ti-6Al-4V substrates. It was confirmed both experimentally and by thermodynamic calculations that the formation of the TiN layer and some internal porosity can be explained by the reaction of the $\mathrm{NH}_{4} \mathrm{Cl}$ activator with the titanium substrate, forming volatile gas species. Simultaneous deposition of $\mathrm{Mo}$ and $\mathrm{Al}$ on powder metallurgy Ti-6Al-4V can be achieved with a pack composition containing $5 \mathrm{wt} \% \mathrm{Al}-35 \mathrm{wt} \% \mathrm{Mo}$, as metal donors and $3 \mathrm{wt} \% \mathrm{NH}_{4} \mathrm{Cl}$ activator. The coating consists of an internal Mo-rich layer as well and $\mathrm{TiN}, \mathrm{TiAl}$ and $\mathrm{Ti}_{2} \mathrm{AlN}$. Increasing the amount of $\mathrm{Al}$ leads to the formation of $\mathrm{AlN}$, in agreement with thermodynamic cal- culations. Wrought Ti-6Al-4V substrates also formed an inner Morich layer and TiN, however the formation of Ti-Al mixed nitrides $\left(\mathrm{Ti}_{2} \mathrm{AlN}, \mathrm{Ti}_{3} \mathrm{AlN}\right)$ instead of the formation of TiAl phase was observed. The difference in the phases formed is attributed to the different microstructure of the substrates: powder metallurgy substrates have courser grain size and some porosity present. No diffusion of Mo was observed onto pure Ti powder metallurgy substrate, during Mo$\mathrm{Al}$ co-deposition with $\mathrm{NH}_{4} \mathrm{Cl}$ activator, using similar pack compositions as for Ti-6Al-4V substrates. Therefore it can be concluded that the presence of $\mathrm{Al}$ and $\mathrm{V}$ alloying elements modifies the diffusion of Mo into the substrate during Mo-Al co-deposition by pack cementation.

\section{Acknowledgments}

The authors would like to thank the funding provided for this research by the Regional Government of Madridthrough the project S2013/MIT-2862 (MULTIMAT-CHALLENGE-CM), and by the Ministry of Economy and Competitiveness of Spain through the project MAT2012/38650-C02-01 


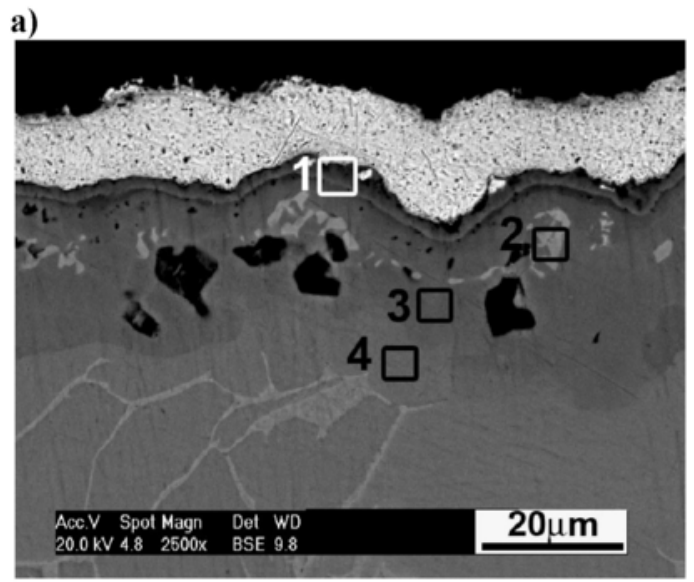

\begin{tabular}{|l|l|l|l|l|}
\hline \multirow{2}{*}{ Layer } & \multicolumn{4}{|l|}{ Atomic \% } \\
\cline { 2 - 5 } & $\mathrm{Ti}$ & $\mathrm{Mo}$ & $\mathrm{Al}$ & $\mathrm{N}$ \\
\hline 1 & 49 & 0 & 2 & 49 \\
\hline 2 & 46 & 5 & 22 & 27 \\
\hline 3 & 49 & 0 & 23 & 28 \\
\hline 4 & 52 & 0 & 16 & 35 \\
\hline
\end{tabular}

EDS analysis of powder metallurgy Ti$6 \mathrm{Al}-4 \mathrm{~V}$ substrates molybdenizedaluminized at $1000^{\circ} \mathrm{C}$ for $6 \mathrm{~h}$ in argon atmosphere using a pack with composition of $35 \% \mathrm{wt} \mathrm{Mo,} 5 \mathrm{wt} \% \mathrm{Al}$, $3 \%$ wt $\mathrm{NH}_{4} \mathrm{Cl}$

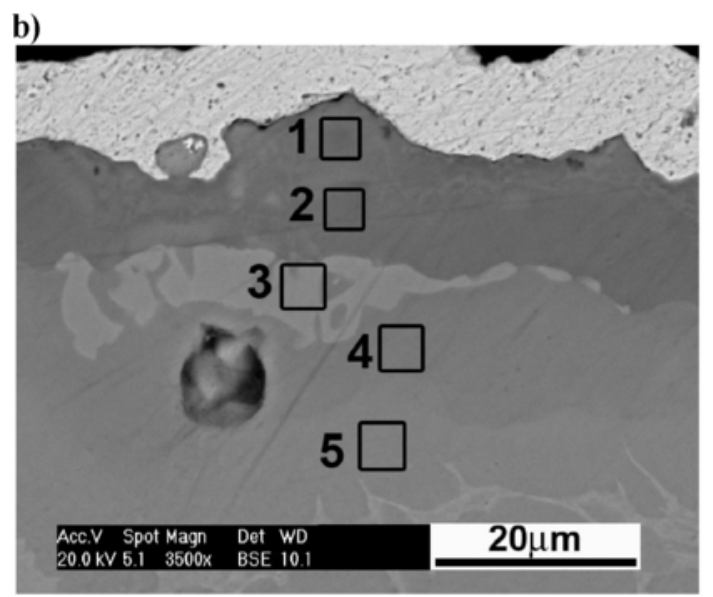

\begin{tabular}{|l|l|l|l|l|}
\hline \multirow{2}{*}{ Layer } & \multicolumn{4}{|l|}{ Atomic \% } \\
\cline { 2 - 5 } & $\mathrm{Ti}$ & $\mathrm{Mo}$ & $\mathrm{Al}$ & $\mathrm{N}$ \\
\hline 1 & 37 & 4 & 59 & 0 \\
\hline 2 & 41 & 1 & 39 & 19 \\
\hline 3 & 48 & 4 & 29 & 19 \\
\hline 4 & 63 & 0 & 21 & 16 \\
\hline 5 & 64 & 0 & 10 & 26 \\
\hline
\end{tabular}

EDS analysis of powder metallurgy Ti$6 \mathrm{Al}-4 \mathrm{~V}$ substrates molybdenizedaluminized at $1000^{\circ} \mathrm{C}$ for $6 \mathrm{~h}$ in argon atmosphere using a pack with composition of $30 \% \mathrm{wt} \mathrm{Mo,} 10 \mathrm{wt} \% \mathrm{Al}$, $3 \%$ wt $\mathrm{NH}_{4} \mathrm{Cl}$

Fig. 6. SEM images of cross section (BSE mode) and EDS analysis of powder metallurgy Ti-6Al-4V substrates molybdenized-aluminized at $1000^{\circ} \mathrm{C}$ for $6 \mathrm{~h}$ in argon atmosphere using a pack with composition of a) $35 \%$ wt $\mathrm{Mo}, 5 \mathrm{wt} \% \mathrm{Al}, 3 \% \mathrm{wt} \mathrm{NH}_{4} \mathrm{Cl}$ b) $30 \% \mathrm{wt} \mathrm{Mo,} 10 \mathrm{wt} \% \mathrm{Al}, 3 \% \mathrm{wt} \mathrm{NH} \mathrm{Cl}_{4}$

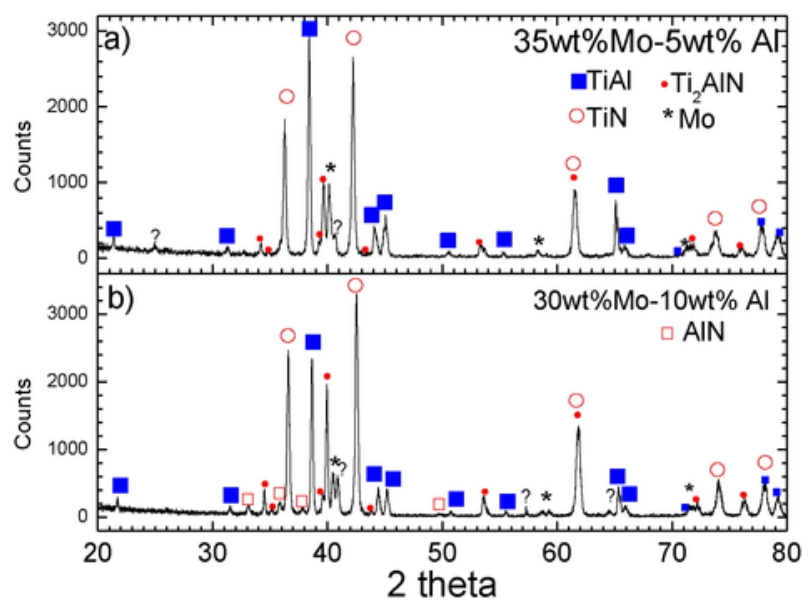

Fig. 7. X-Ray Diffraction diagram of powder metallurgy Ti-6Al-4V substrates molybdenized-aluminized at $1000^{\circ} \mathrm{C}$ for $6 \mathrm{~h}$ in argon atmosphere using a pack with composition of a) $35 \% \mathrm{wt} \mathrm{Mo}, 5 \mathrm{wt} \% \mathrm{Al}, 3 \% \mathrm{wt} \mathrm{NH}_{4} \mathrm{Cl}$ b) $30 \% \mathrm{wt} \mathrm{Mo}, 10 \mathrm{wt} \% \mathrm{Al}, 3 \% \mathrm{wt} \mathrm{NH}_{4} \mathrm{Cl}$ The identification of phases was according to the International Centre for Diffraction Data (ICDD) database: TiAl (03-065-0428), (TiN (038-1420), Ti ${ }_{2} \mathrm{AlN}$ (03-065-3496), Mo (042-1120), AlN (01-079-2497) 
a)

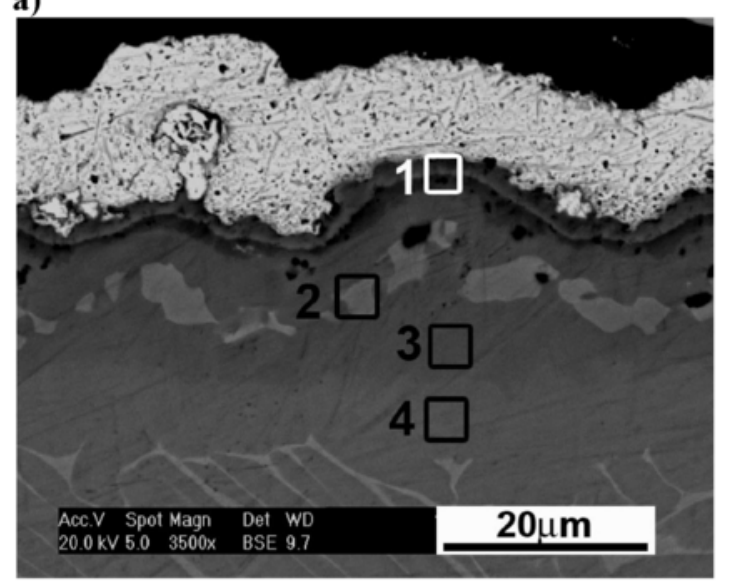

b)

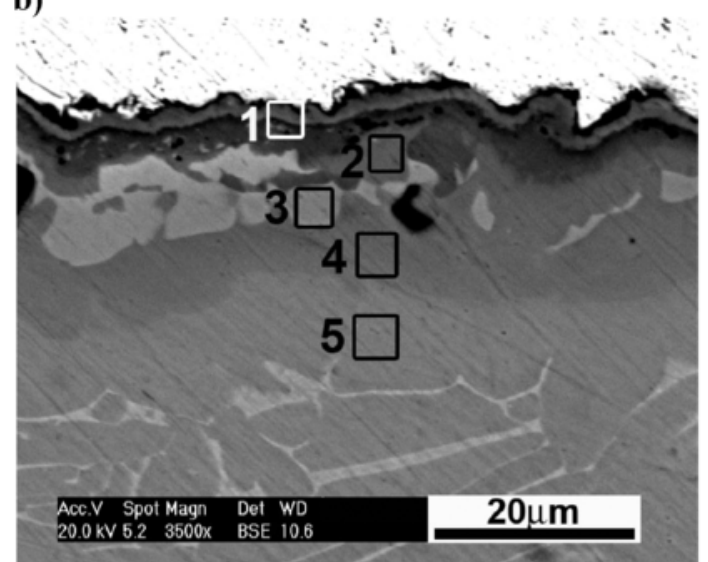

\begin{tabular}{|l|l|l|l|l|}
\hline \multirow{2}{*}{ Layer } & \multicolumn{4}{|l|}{ Atomic \% } \\
\cline { 2 - 5 } & Ti & Mo & Al & N \\
\hline 1 & 51 & 1 & 25 & 23 \\
\hline 2 & 43 & 6 & 24 & 27 \\
\hline 3 & 54 & 0 & 18 & 28 \\
\hline 4 & 62 & 0 & 10 & 28 \\
\hline
\end{tabular}

EDS analysis of wrought Ti-6Al-4V substrates molybdenized-aluminized at $1000^{\circ} \mathrm{C}$ for $6 \mathrm{~h}$ in argon atmosphere using a pack with composition of $35 \%$ wt Mo, $5 w t \% \mathrm{Al}, 3 \%$ wt $\mathrm{NH}_{4} \mathrm{Cl}$

\begin{tabular}{|l|l|l|l|l|}
\hline \multirow{2}{*}{ Layer } & \multicolumn{4}{|l|}{ Atomic \% } \\
\cline { 2 - 5 } & $\mathrm{Ti}$ & $\mathrm{Mo}$ & $\mathrm{Al}$ & $\mathrm{N}$ \\
\hline 1 & 58 & 0 & 13 & 29 \\
\hline 2 & 50 & 0 & 21 & 29 \\
\hline 3 & 47 & 3 & 26 & 24 \\
\hline 4 & 51 & 0 & 22 & 27 \\
\hline 5 & 64 & 0 & 10 & 26 \\
\hline
\end{tabular}

EDS analysis of wrought Ti-6Al-4V substrates molybdenized-aluminized at $1000^{\circ} \mathrm{C}$ for $6 \mathrm{~h}$ in argon atmosphere using a pack with composition of $30 \%$ wt Mo, $10 \mathrm{wt} \% \mathrm{Al}, 3 \% \mathrm{wt} \mathrm{NH}_{4} \mathrm{Cl}$

Fig. 8. SEM images of cross section (BSE mode) and EDS analysis of wrought Ti-6Al-4V substrates molybdenized-aluminized at $1000^{\circ} \mathrm{C}$ for $6 \mathrm{~h}$ in argon atmosphere using a pack with composition of a) $35 \% \mathrm{wt} \mathrm{Mo,} 5 \mathrm{wt} \% \mathrm{Al}, 3 \% \mathrm{wt} \mathrm{NH} \mathrm{Nl}_{4} \mathrm{Cl}$ b) $30 \% \mathrm{wt} \mathrm{Mo,} 10 \mathrm{wt} \% \mathrm{Al}, 3 \% \mathrm{wt} \mathrm{NH}_{4} \mathrm{Cl}$

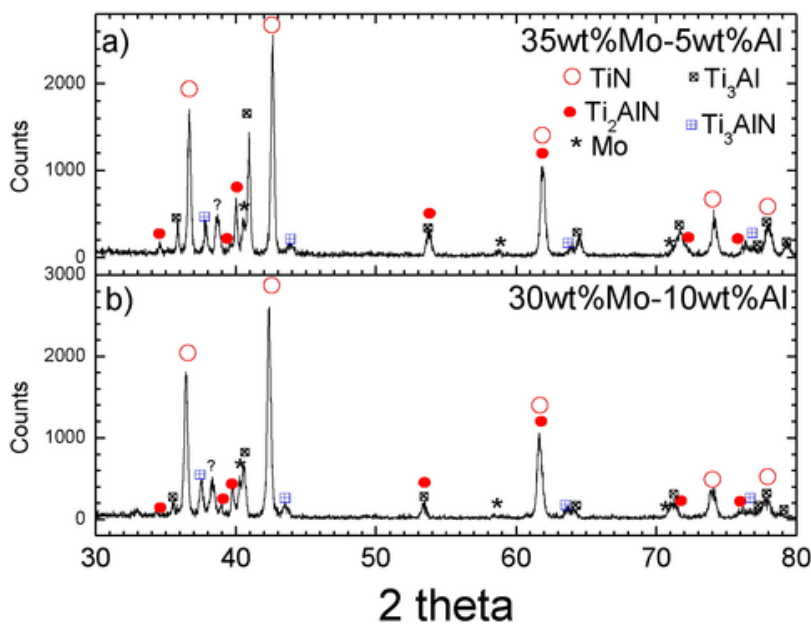

Fig. 9. X-Ray Diffraction diagram of wrought Ti-6Al-4V substrates molybdenized-aluminized at $1000^{\circ} \mathrm{C}$ for $6 \mathrm{~h}$ in argon atmosphere using a pack with composition of a)

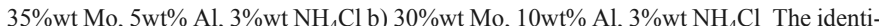
fication of phases was according to the International Centre for Diffraction Data (ICDD) database: $\mathrm{Ti}_{3} \mathrm{Al}$ (052-0859), TiN (038-1420), $\mathrm{Ti}_{2} \mathrm{AlN}$ (03-065-3496), Mo (042-1120), $\mathrm{Ti}_{3} \operatorname{AlN}(037-1140)$ 

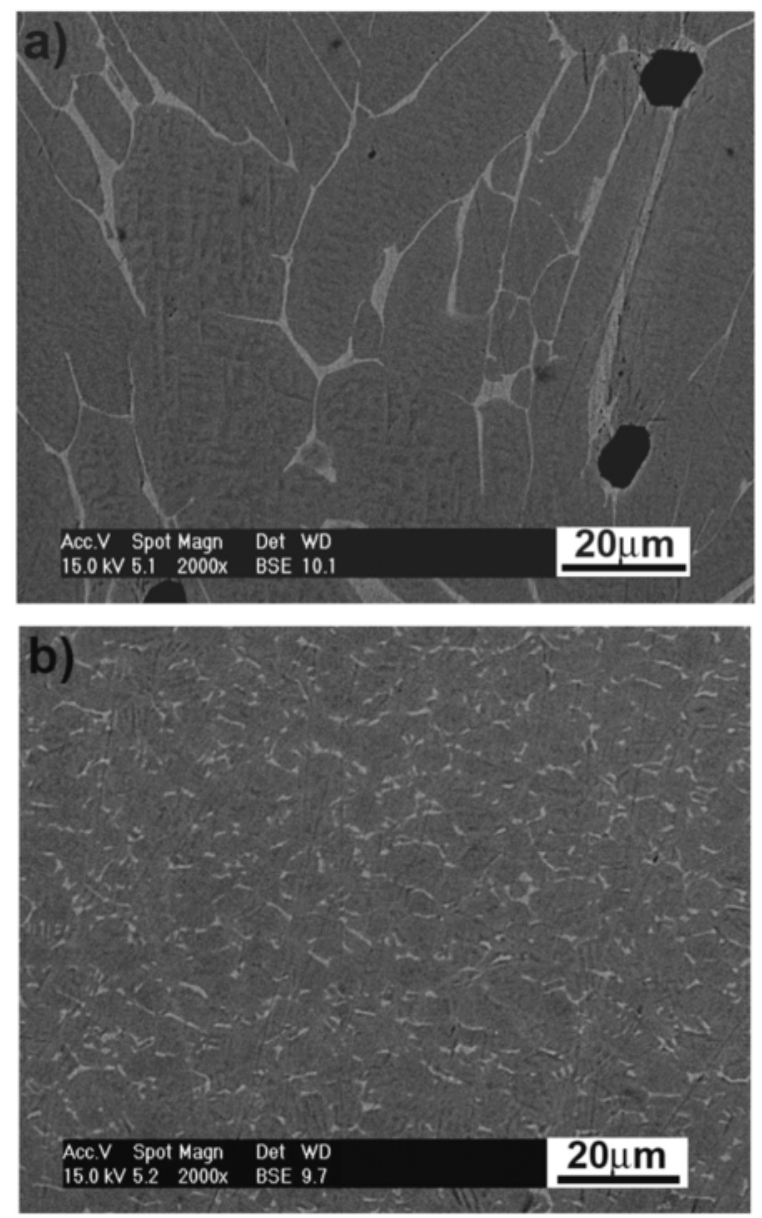

Fig. 10. Microstructure (SEM, BSE mode) of the substrates a) powder metallurgy Ti-6Al-4V, b) wrought Ti-6Al-4V 

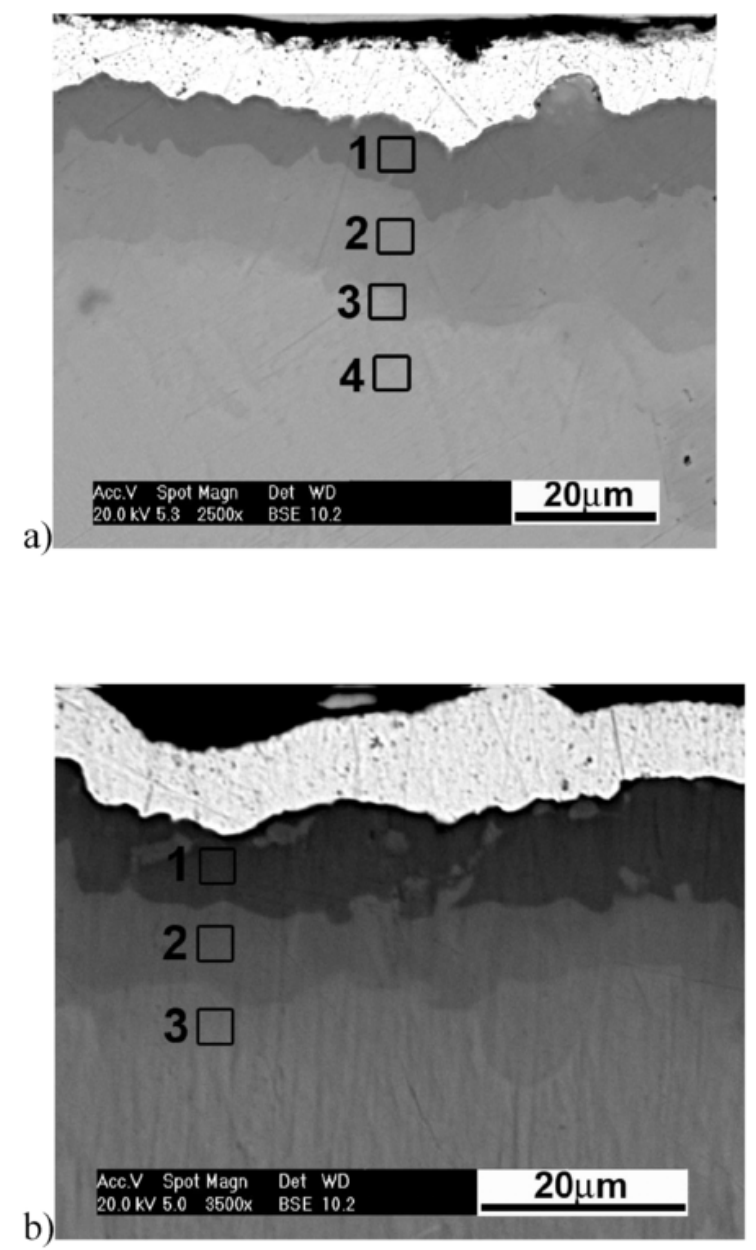

\begin{tabular}{|l|l|l|l|l|}
\hline \multirow{2}{*}{ Layer } & \multicolumn{4}{|l|}{ Atomic \% } \\
\cline { 2 - 5 } & $\mathrm{Ti}$ & $\mathrm{Mo}$ & $\mathrm{Al}$ & $\mathrm{N}$ \\
\hline 1 & 36 & 0 & 26 & 38 \\
\hline 2 & 65 & 0 & 13 & 22 \\
\hline 3 & 59 & 0 & 8 & 33 \\
\hline 4 & 78 & 0 & 0 & 22 \\
\hline
\end{tabular}

EDS analysis of powder metallurgy Titanium substrates molybdenizedaluminized at $1000^{\circ} \mathrm{C}$ for $6 \mathrm{~h}$ in argon atmosphere using a pack with composition of $35 \%$ wt Mo, $5 \mathrm{wt} \% \mathrm{Al}, 3 \% \mathrm{wt} \mathrm{NH}_{4} \mathrm{Cl}$

\begin{tabular}{|l|l|l|l|l|}
\hline \multirow{2}{*}{ Layer } & \multicolumn{4}{|l|}{ Atomic \% } \\
\cline { 2 - 5 } & $\mathrm{Ti}$ & $\mathrm{Mo}$ & $\mathrm{Al}$ & $\mathrm{N}$ \\
\hline 1 & 33 & 0 & 36 & 31 \\
\hline 2 & 46 & 0 & 20 & 34 \\
\hline 3 & 56 & 0 & 10 & 34 \\
\hline
\end{tabular}

EDS analysis of powder metallurgy Titanium substrates molybdenizedaluminized at $1000^{\circ} \mathrm{C}$ for $6 \mathrm{~h}$ in argon atmosphere using a pack with composition of $30 \%$ wt $\mathrm{Mo}, 10 \mathrm{wt} \% \mathrm{Al}, 3 \%$ wt $\mathrm{NH}_{4} \mathrm{Cl}$

Fig. 11. SEM images of cross section (BSE mode) and EDS analysis of powder metallurgy Titanium substrates molybdenized-aluminized at $1000^{\circ} \mathrm{C}$ for $6 \mathrm{~h}$ in argon atmosphere using a pack with composition of a) $35 \% \mathrm{wt} \mathrm{Mo,} 5 \mathrm{wt} \% \mathrm{Al}, 3 \% \mathrm{wt} \mathrm{NH}_{4} \mathrm{Cl}$ b) $30 \% \mathrm{wt} \mathrm{Mo}, 10 \mathrm{wt} \% \mathrm{Al}, 3 \% \mathrm{wt} \mathrm{NH} \mathrm{Cl}_{4}$

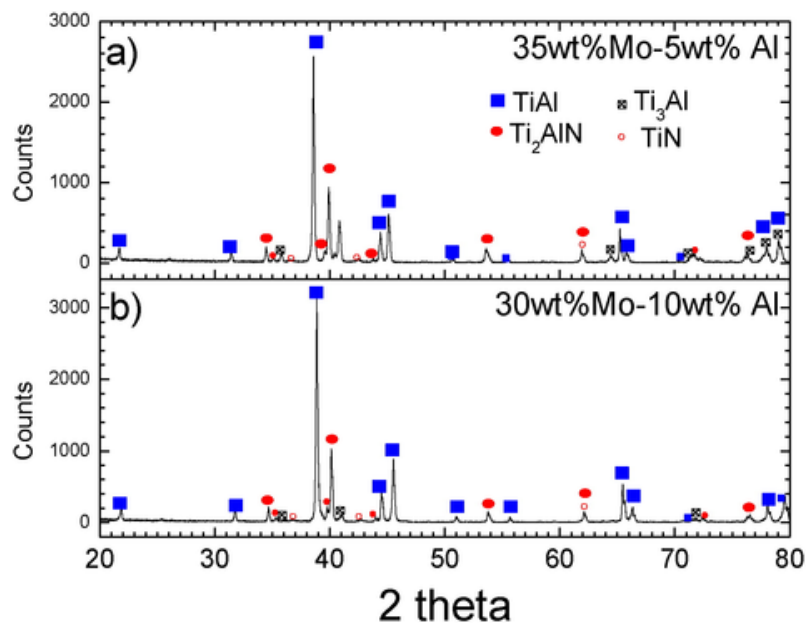

Fig. 12. X-Ray Diffraction diagram of powder metallurgy Ti substrates molybdenizedaluminized at $1000^{\circ} \mathrm{C}$ for $6 \mathrm{~h}$ in argon atmosphere using a pack with composition of a) $35 \%$ wt $\mathrm{Mo}, 5 \mathrm{wt} \% \mathrm{Al}, 3 \% \mathrm{wt} \mathrm{NH}_{4} \mathrm{Cl}$ b) $30 \% \mathrm{wt} \mathrm{Mo,} 10 \mathrm{wt} \% \mathrm{Al}, 3 \% \mathrm{wt} \mathrm{NH}_{4} \mathrm{Cl}$ The identification of phases was according to the International Centre for Diffraction Data (ICDD) database: TiAl (03-065-0428), $\mathrm{Ti}_{2} \mathrm{AlN}$ (03-065-3496), $\mathrm{Ti}_{3} \mathrm{Al}$ (052-0859), TiN (038-1420)

\section{References}

[1] W F Ho, C P Ju, J H C Lin, Structure and properties of cast binary Ti-Mo alloys, Biomaterials 20 (22) (1999) 2115-2122, http://dx doi org/10 1016/ s0142-9612(99)00114-3

[2] H Anada, Y Shida, Effect of Mo addition on the oxidation behavior of TiAl intermetallic compound, Mater Trans JIM 36 (4) (1995) 533-539

[3] Y Sugizaki, T Yasunaga, H Tomari, Improvement of corrosion resistance of titanium by co-implantation, Surf Coat Technol 83 (1-3) (1996) 167-174, http://dx doi org/10 1016/0257-8972(95)02834-x

[4] G Akdogan, T A Stolarski, S Tobe, Surface fatigue of molybdenum and Albronze coatings in unlubricated rolling/sliding contact, Wear 253 (3-4) (2002) 319-330, http://dx doi org/10 1016/s0043-1648(02)00152-7

[5] B Hwang, S Lee, J Ahn, Correlation of microstructure and wear resistance of molybdenum blend coatings fabricated by atmospheric plasma spraying, Mater Sci Eng A 366 (1) (2004) 152-163, http://dx doi org/10 1016/j msea 200309 062

[6] $\mathrm{K} \mathrm{W} \mathrm{Ng}$, et al, Laser cladding of copper with molybdenum for wear resistance enhancement in electrical contacts, Appl Surf Sci 253 (14) (2007) 6236-6241, http://dx doi org/10 1016/j apsusc 200701086

[7] G Jin, et al, Tribological properties of molybdenum coatings sprayed by electro-thermal explosion directional spraying, Surf Coat Technol 201 (15) (2007) 6678-6680, http://dx doi org/10 1016/j surfcoat 200609028

[8] W -p Liang, et al, Double glow plasma surface molybdenizing of Ti2AlNb, Surf Coat Technol 201 (9-11) (2007) 5068-5071, http://dx doi org/10 1016/j surfcoat 200607196

[9] B Tang, et al, Tribological behavior of plasma Mo-N surface modified Ti-6Al-4V alloy, Surf Coat Technol 179 (2-3) (2004) 333-339, http://dx doi org/10 1016/s0257-8972(03)00855-7 
[10] W -p Liang, et al, Tribological behaviors of Ti-6Al-4V alloy with surface plasma molybdenized layer, Surf Coat Technol 228 (2013) S249-S253, http:// dx doi org/10 1016/j surfcoat 201205134

[11] B Nengjun, et al, Tribological behaviors of Ti6AI4V with surface plasma molybdenized, Mater Sci Forum 704-705 (2012) 1253-1258, http://dx doi org/ 10 4028/www scientific net/MSF 704-705 1253

[12] F Ailan, et al, Friction and wear behaviors of Mo-N modified Ti6Al4V alloy in Hanks' solution, Surf Coat Technol 228 (2013) S419-S423, http://dx doi org/ 10 1016/j surfcoat 201205046

[13] A Fan, et al, Corrosion resistance of molybdenum nitride modified Ti6Al4V alloy in $\mathrm{HCl}$ solution, J Wuhan Univ Technol -Mater Sci Ed 23 (3) (2008) 358-361, http://dx doi org/10 1007/s11595-007-3358-5

[14] Z Pingze, et al, Surface plasma molybdenized burn-resistant titanium alloy, Key Eng Mater 353-358 (2007) 1837-1841

[15] Z D Xiang, J S Burnell-Gray, P K Datta, Aluminide coating formation on nickel-base superalloys by pack cementation process, J Mater Sci 36 (23) (2001) 5673-5682, http://dx doi org/10 1023/a:1012534220165

[16] S A Tsipas, et al, Boride coatings obtained by pack cementation deposited on powder metallurgy and wrought Ti and Ti-6Al-4V, Surf Coat Technol 205 (7) (2010) 2340-2347, http://dx doi org/10 1016/j surfcoat 201009 026

[17] Z D Xiang, P K Datta, Low temperature aluminisation of alloy steels by pack cementation process, Mater Sci Technol 22 (10) (2006) 1177-1184, http://dx doi org/10 1179/174328406x118366

[18] R Mevrel, C Duret, R Pichoir, Pack cementation processes, Mater Sci Technol 2 (3) (1986) 201-206

[19] A Squillace, et al, The control of the composition and structure of aluminide layers formed by vapour aluminising, Surf Coat Technol 120 (1999) 118-123, http://dx doi org/10 1016/s0257-8972(99)00347-3

[20] X Peng, et al, Comparison of molybdenizing and NiCrAlY coating on Ti and Ti-6Al-4V, Rare Metals 28 (1) (2009) 49-56, http://dx doi org/10 1007/ s12598-009-0010-

[21] X M Peng, et al, Surface molybdenizing on titanium by halide-activated pack cementation, Surf Coat Technol 203 (20-21) (2009) 3306-3311, http://dx doi org/10 1016/j surfcoat 200904008

[22] J Li, C Q Xia, Y Gu, Effect of temperature on microstructure of molybdenum diffusion coating on titanium substrate, J Cent S Univ Technol 11 (1) (2004) 15-18, http://dx doi org/10 1007/s11771-004-0003-8

[23] C Leyens, M Peters, W A Kaysser, Intermetallic Ti-Al coatings for protection of titanium alloys: oxidation and mechanical behavior, Surf Coat Technol 94-5 (1-3) (1997) 34-40, http://dx doi org/10 1016/ s0257-8972(97)00472-6

[24] A Hirose, T Ueda, K F Kobayashi, Wear And Oxidation Properties Of Titanium Aluminides Formed On Titanium Surface By Laser Alloying, Mater Sci Eng A 160 (1) (1993) 143-153, http://dx doi org/10 1016/ 0921-5093(93)90507-b

[25] Z W Li, et al Improved oxidation resistance of $\mathrm{Ti}$ with a thermal sprayed Ti3Al(O)-Al2O3 composite coating, Scr Mater 48 (12) (2003) 1649-1653, http://dx doi org/10 1016/s1359-6462(03)00133-7

[26] M Z Alam, D K Das, Effect of cracking in diffusion aluminide coatings on their cyclic oxidation performance on Ti-based IMI-834 alloy, Corros Sci 51 (6) (2009) 1405-1412, http://dx doi org/10 1016/j corsci 200903027

[27] I Gurrappa, Effect of aluminizing on the oxidation behavior of the titranium alloy, IMI 834, Oxid Met 56 (1-2)(2001) 73-87, http://dx doi org/10 1023/a: 1010343403143

[28] Y G Zhao, et al, Effect of pre-oxidation on the properties of aluminide coating layers formed on Ti alloys, J Alloys Compd 391 (1-2) (2005) 136-140, http:// dx doi org/10 1016/j jallcom 200407073

[29] W Zhou, et al, Oxidation behavior of the Y2O3-modified aluminide coating on Ti-6Al-4V alloy, Mater Sci Eng A 458 (1-2) (2007) 34-38, http://dx doi org/ 10 1016/j msea 200701111

[30] G P Cammarota, A Casagrande, G Sambogna, Effect of Ni, Si and Cr in the structural formation of diffusion aluminide coatings on commercial-purity titanium, Surf Coat Technol 201 (1-2) (2006) 230-242, http://dx doi org/10 1016/ j surfcoat 11125

[31] D Q Wang, Z Y Shi, Y L Teng, Microstructure and oxidation of hot-dip aluminized titanium at high temperature, Appl Surf Sci 250 (1-4) (2005) 238-246, http://dx doi org/10 1016/j apsusc 200501002

[32] Y Wang, et al, Oxidation resistance and corrosion behavior of hot-dip aluminized coatings on commercial-purity titanium, Surf Coat Technol 206 (6) (2011) 1277-1282, http://dx doi org/10 1016/j surfcoat 201108042

[33] H -P Xiong, et al, Liquid-phase aluminizing and siliconizing at the surface of a Ti60 alloy and improvement in oxidation resistance, Mater Sci Eng A 433 (1-2) (2006) 108-113, http://dx doi org/10 1016/j msea 200606059

[34] Z G Zhang, et al, Effect of hot-dip aluminizing on the oxidation resistance of Ti-6Al-4V alloy at high temperatures, Corros Sci 55 (2012) 187-193, http:// dx doi org/10 1016/j corsci 201110029
[35] I Gurrappa, A K Gogia, Development of oxidation resistant coatings for titanium alloys, Mater Sci Technol 17 (5) (2001) 581-587

[36] D K Das, Z Alam, Cyclic oxidation behaviour of aluminide coatings on Tibase alloy IMI-834 at 750 degrees C, Surf Coat Technol 201 (6) (2006) 3406-3414, http://dx doi org/10 1016/j surfcoat 200607230

[37] D K Das, S P Trivedi, Microstructure of diffusion aluminide coatings on Tibase alloy IMI-834 and their cyclic oxidation behaviour at 650 degrees $C$, Mater Sci Eng A 367 (1-2) (2004) 225-233, http://dx doi org/10 1016/j msea 200310196

[38] S P Trivedi, D K Das, Microstructural aspects of plain aluminide and Pt-aluminide coatings on Ti-base alloy IMI-834, Intermetallics 13 (10) (2005) 1122-1133, http://dx doi org/10 1016/j intermet 200502006

[39] C G Zhou, et al , A study of aluminide coatings on TiAl alloys by the pack cementation method, Mater Sci Eng A 341 (1-2) (2003) 169-173, http://dx doi org/10 1016/s0921-5093(02)00197-1

40] M Sujata, S Bhargava, S Sangal, On the formation of TiAl3 during reaction between solid Ti and liquid Al, J Mater Sci Lett 16 (14) (1997) 1175-1178, $\mathrm{http} / / / \mathrm{dx}$ doi org/10 1007/bf02765402

[41] R W Richards, et al , Metallurgy Of Continuous Hot-Dip Aluminizing, Int Mater Rev 39 (5) (1994) 191-212

[42] S A Tsipas, E Gordo, A Jimenez-Morales, Oxidation and corrosion protection by halide treatment of powder metallurgy Ti and Ti6Al4V alloy, Corros Sci 88 (2014) 263-274, http://dx doi org/10 1016/j corsci 201407037

[43] J O Andersson, et al, THERMO-CALC \& DICTRA, computational tools for materials science, Calphad 26 (2) (2002) 273-312, http://dx doi org/10 1016/ s0364-5916(02)00037-8

[44] N Voudouris, C Christoglou, G N Angelopoulos, Formation of aluminide coatings on nickel by a fluidised bed CVD process, Surf Coat Technol 141 (2-3) (2001) 275-282, http://dx doi org/10 1016/ s0257-8972(01)01193-8

[45] Z D Xiang, J S Burnell-Gray, P K Datta, Conditions for codeposition of Al and $\mathrm{Cr}$ on Ni base superalloys by pack cementation process, Surf Eng 17 (4) (2001) 287-294, http://dx doi org/10 1179/026708401101517890

[46] Z D Xiang, P K Datta, Deposition of silicon modified aluminide coatings on nickel base superalloys by pack cementation process, Mater Sci Technol 19 (7) (2003) 935-942, http://dx doi org/10 1179/026708303225002965

[47] S C Kung, R A Rapp, Analyses of the gaseous species in halide-activated cemention coating packs, Oxid Met 32 (1-2) (1989) 89-109, http://dx doi org/10 1007/bf00665270

[48] M A Harper, R A Rapp, Codeposited chromium and silicon diffsuion coating for Fe-based alloys via pack cementation, Oxid Met 42 (3-4) (1994) 303-333, http://dx doi org/10 1007/bf01052029

[49] R Bianco, M A Harper, R A Rapp, Codepositing elements by halide-activated pack cementation, JOM J Miner Met Mater Soc 43 (11) (1991) 68-73

[50] Z D Xiang, P K Datta, Codeposition of Al and Si on nickel base superalloys by pack cementation process, Mater Sci Eng A 356 (1-2) (2003) 136-144, http:// $\mathrm{dx}$ doi org/10 1016/s0921-5093(03)00107-2

[51] Z D Xiang, et al, Co-deposition of aluminide and silicide coatings on gammaTiAl by pack cementation process, J Mate Sci 38 (1) (2003) 19-28, http://dx doi org/10 1023/a:1021149413017

[52] M Qiao, C Zhou, Codeposition of $\mathrm{Co}$ and $\mathrm{Al}$ on nickel base superalloys by pack cementation process, Surf Coat Technol 206 (11-12) (2012) 2899-2904, http://dx doi org/10 1016/j surfcoat 201112019

[53] F D Geib, R A Rapp, Simultaneous chromizinng-aluminizing coating of lowalloy steels by halide-activated, pack cementation process, Oxid Met , 40 (3-4) (1993) 213-228, http://dx doi org/10 1007/bf00664491

[54] S A Tsipas, et al, Boroaluminide coatings on ferritic-martensitic steel deposited by low-temperature pack cementation, Surf Coat Technol 202 (14) (2008) 3263-3271, http://dx doi org/10 1016/j surfcoat 200711034

[55] L Bolzoni, et al, Mechanical behaviour of pressed and sintered titanium alloys obtained from prealloyed and blended elemental powders, J Mech Behav Biomed Mater 14 (2012) 29-38, http://dx doi org/10 1016/j jmbbm 201205013

[56] R Boyer, G Welsch, E W Collings (Eds ), Materials Properties Handbook:Titanium Alloys, ASM International, Metals Park, OH, 1994

[57] M W Barsoum, M Ali, T El-Raghy, Processing and characterization of Ti2AlC, Ti2AlN, and Ti2AlC0 5N0 5, Metall Mater Trans A Phys Metall Mater Sci 31 (7) (2000) 1857-1865, http://dx doi org/10 1007/ s11661-006-0243-3

[58] A Czyrska-Filemonowicz, et al, Transmission electron microscopy and atomic force microscopy characterisation of titanium-base alloys nitrided under glow discharge, Acta Mater 53 (16) (2005) 4367-4377, http://dx doi org/10 1016/j actamat 200505035 